\title{
Defining the Maturity Levels for Implementing Industrial Logistics Practices in Construction
}

\author{
Müge Tetik ${ }^{1 \star}$, Antti Peltokorpi ${ }^{1}$, Olli Seppänen ${ }^{1}$ and Jan Holmström ${ }^{2}$ \\ ${ }^{1}$ School of Engineering, Department of Civil Engineering, Aalto University, Espoo, Finland, ${ }^{2}$ School of Science, Department of \\ Industrial Engineering and Management, Aalto University, Espoo, Finland
}

Logistics practices are processes that require alignment and coordination among project actors to support successful construction operations. While recent research has underlined the effects of single material logistics practices on project performance, practitioners need more knowledge on development paths toward successful overall logistics solutions. Based on a review of current practices obtained from the literature, this research proposes the maturity levels of planning, organizing, operating, use of technology, and information flow regarding the logistics practices in construction. Moreover, the study devises a recommended order for implementing logistics

Edited by:

Zhen Chen,

University of Strathclyde,

United Kingdom

Reviewed by:

Susy Fatena Rostiyanti,

Podomoro university, Indonesia Jamal Younes Omran,

Tishreen University, Syria Frode Drevland

Norwegian University of Science and

Technology, Norway

${ }^{*}$ Correspondence:

Müge Tetik

muge.tetik@aalto.fi

Specialty section:

This article was submitted to Construction Management,

a section of the journal

Frontiers in Built Environment

Received: 12 July 2021 Accepted: 20 December 2021 Published: 12 January 2022

Citation:

Tetik M, Peltokorpi A, Seppänen O and Holmström J (2022) Defining the Maturity Levels for Implementing Industrial Logistics Practices in Construction.

Front. Built Environ. 7:740086. doi: 10.3389/fbuil.2021.740086 practices and investigates how companies can advance their logistics maturity from one level to the next. The proposed model has been validated via case examples from the industry. The paper contributes to construction logistics research by describing how companies can navigate development efforts to gradually improve their logistics practices. Future research could conduct more case studies within different project contexts.

Keywords: construction logistics, maturity model, industrial logistics, operations management, construction operations

\section{INTRODUCTION}

Prompt and efficient material flow is crucial for successful construction operations as it ensures that the on-site workforce will receive the required materials at the required time. Construction logistics means managing the material flows i.e., supplying the right materials at the right time to the right customer on the construction site (Janné 2018). Previous studies estimate that cost savings between 10 and $30 \%$ can be obtained through specific efficient logistics practices (Said and El-Rayes 2014; Tetik et al., 2019). The use of proper material logistics decreases the time spent on searching for materials, thus leading to reductions in wasted labor time (Lange and Schilling 2015; Tetik et al., 2018). Despite the existence of several successful case examples, the implementation of logistics practices in the construction industry lags behind that of other industries (Lönngren et al., 2010; Said and El-Rayes 2014).

Poor logistics practices occur in the construction industry for several reasons, including the temporary and fragmented nature of construction projects (which affects the implementation of long-term change), the lack of pre-planning activities (Sullivan et al., 2011), the lack of competence (Berawi et al., 2012), and overly high logistics costs, all of which can deter contractors from investing in logistics (Vrijhoef and Koskela 2000). Because of the fragmented organizing of construction operations, subcontractors often order and manage project materials themselves. This fragmentation and lack of coordination has led to a situation in which only around $40 \%$ of material deliveries are executed with accurate information, location, and time (Thunberg and Persson 2014). 
Problems related to poor logistics consume a large amount of time and resources (Ekeskär and Rudberg 2016). Poor logistics management can cause double handling of materials (Fearne and Fowler 2006) and waste of labor time (Josephson and Saukkoriipi 2005). Information updates on material flow are important for on-site management so that the labor force can adjust to possible changes in material availability. If the delivery of materials is late, subsequent operations will also be delayed. Variability in material demand and supply directly affects project performance, decreases quality and safety, and increases cost and duration (Arbulu and Ballard 2004).

The success of a construction project depends on the coordination of the on-site and external logistics (Ying et al., 2014). Several solutions to these logistics problems can be found in the literature, and multiple logistics practices exist for different material and product types, such as the use of third-party logistics (Ekeskär and Rudberg 2016), consolidation centres (Arbulu and Ballard 2004), material kitting (Tetik et al., 2020), and vendormanaged inventories (Tanskanen et al., 2009). However, this multitude of available sub-solutions can lead to confusion among practitioners as it is often unclear which of the proposed solutions are most essential and generically useful and which are more specific to certain circumstances. To ease similar implementation issues, maturity models have proven useful in several other contexts.

Maturity models determine the maturity of selected domains based on a series of criteria (De Bruin et al., 2005). Maturity represents the attainment of full growth (Maier et al., 2012) and full development (Cookie-Davies 2004). For instance, the use of a maturity model for digitalization in manufacturing has brought several benefits to the industry, including increased process efficiency, lower operational costs, and increased safety and sustainability (Sjödin et al., 2018). Transitioning to highly advanced solutions is difficult because they require several enablers that might be impossible to develop instantaneously. For this reason, determining the steps of maturity is crucial in order for practitioners to gradually learn to excel at logistics operations. A company's position in the logistics maturity model can determine the next steps in its development work.

While recent research has underlined the effects of material logistics practices on project performance, such as productivity and waste, not a single best practice for logistics solutions currently exists. Therefore, practitioners need more knowledge on development paths toward successful overall logistics solutions. To address this gap, this study seeks to define the different maturity levels of logistics practices in construction and then outline the development paths for project actors to progress from amateur to more advanced and industrial logistics solutions. The purpose of the present research is to determine a proposed order of gradual logistics developments in construction by using the maturity level approach. The theoretical contribution of this study is a new model for logistics maturity evaluation in the construction industry. The practical contribution is a suggestion of how appropriate logistics practices could be gradually implemented to improve logistics capabilities and ultimately increase the performance of companies and their projects.

To specify the need for a maturity model for construction logistics, literature on the role and challenges of material logistics in construction was reviewed. Next, existing logistics practices in construction are reviewed, highlighting the requirements and steps for their implementation. Thereafter, previously developed maturity models from fields of logistics, supply chain management and Industry 4.0 are reviewed, and finally, this literature was synthesized into five relevant maturity model themes and categorized the existing logistic practices under each theme in the logical order of implementation. To validate the themes and the order of the logistic practices that were categorized under each theme, this study analyzed the development of the logistics operations of three companies in the industry. The focus was on the requirements and steps they have taken to achieve these practices, which helped in defining a logical order for implementing logistics practices that reflect the corresponding logistics maturity levels. Finally, the findings are summarized.

\section{LITERATURE REVIEW}

This research combines three research streams: 1) the role and challenges of material logistics in construction, 2) logistics solutions in the construction industry, and 3) maturity models. In reviewing this literature below, the need for advanced logistics solutions in construction is described. Following this, the existing partial solutions were analyzed to define current logistics practices and review different maturity models to define their critical themes. Then, the practices against the themes are mapped to create logical ladders from lower-to higher-level practices.

\section{The Role and Challenges of Material Logistics in Construction}

Material logistics constitutes an important aspect of construction projects as material flow affects the critical factors of a project, including cost, speed, and plan reliability (Sullivan et al., 2011). It is often the case that materials are ordered either behind schedule, which causes suppliers to maintain large supply amounts and material buffers to ensure delivery, or prematurely, which leads to material inventories on-site that can be damaged due to waiting (Vrijhoef and Koskela 2000). Some materials may be purchased just before they are required, which can lead to delays and interruptions in the working schedule. The coordination of logistics practices can be difficult because of the contradictory requirements of achieving operational efficiency while adapting to the dynamic environment (Berndt 2011).

Material logistics is known to affect workflow variability. Material availability may affect the start times and durations of activities, meaning that actual activity times will differ from pre-determined schedules. Problems in workflow variability increase with fluctuations in material delivery dates (Hamzeh et al., 2007). This external variation caused by material supply refers to those factors that are not absolutely regular and predictable and that, therefore, present variability in production, such as irregular demand, product variety in meeting market needs, the interruption of operations to satisfy 
specific customers (Hopp and Spearman 2004), resource changes, machine malfunctions, problems related to equipment (Wambeke et al., 2011), rushing orders, transport breakdowns, and supplier-related problems (Jain et al., 2013). A fully efficient flow refers to a process that loses no time either through delays or wastage (Reddy 2015). If on-site workflow efficiency is increased without also reducing the variation in material deliveries, then the resources would need to be increased exponentially, which is not possible in practice: ordering materials in large quantities to the site leads to a waste of resources in terms of stocking, handling, and transporting of the materials (Poon et al., 2004). However, when material stocks are too low, production can slow down, become disrupted, or even stop altogether (Horman and Thomas 2005; Cheng and Kumar 2015).

One way to address undesirable variation is by having sufficiently large inventory buffers. Companies often use costly intermediate storage to avoid shortfalls in materials on-site (Dallasega et al., 2016). However, large material buffers can lead to congested areas on the job site (Elbeltagi et al., 2004), with materials preventing workers from moving or unloading in limited on-site areas (Leväniemi 2018). The labor force also tends to waste time looking for materials (Arbulu and Ballard 2004), resulting in delays. Some contracts also stipulate that subcontracted workers are responsible for carrying materials on-site.

Even if material deliveries and inventories are appropriately managed, problems can result from the availability and quality of information regarding the materials needed for each site activity. Task-level material requirements are not always generated, and quantities can be misleading if they were identified by a manager rather than by the worker performing the task (Tetik et al., 2018). When extracting quantities of a given material, the manual processes of quantity take-off, bidding, and quantity revision of materials can cause conflicts among construction stakeholders (Castro-Lacouturea and Skibniewski 2003). Although many building information modeling (BIM) tools provide automatic quantity take-off abilities, quantity take-off is generally a manual process. Song and Fisher (2020) state that accurate bill-ofmaterial (BOM) requires LOD400 level models which are not common in practice. Since it usually involves human interpretation, errors are likely to occur (Monteiro and Martins 2013). Incomplete details and inappropriate modeling methods cause deviations in extracted quantities (Khosakitchalert et al., 2019), and inaccurate quantities lead to more challenges in ensuing on-site operations. These problems can increase in severity and become less visible if the main contractor has outsourced the quantity take-off and purchasing responsibilities to subcontractors.

Problems also frequently occur because of the large variety of materials required in projects and the handling of these materials by different project actors. Material procurement requires forward planning rather than firefighting (Barthorpe et al., 2010). Material delivery scheduling must be adaptable so as to respond to inevitable changes in near-term scheduling. Thus, suppliers must stay up to date on project progress to be able to react to the project's needs (Ala-Risku and Kärkkäinen 2006).
Although scientific evidence shows that the role of logistics is significant in construction projects, most companies have not yet realized the importance and benefits of appropriate logistics operations (Fadiya et al., 2015; Sundquist et al., 2018). Most practitioners have not adopted proper logistics management because of the demand for detailed data (Said and El-Rayes 2014). Furthermore, practitioners may be unwilling to adopt logistic innovations because they may not understand exactly how the solutions work (Tanskanen et al., 2015). Some have expressed concern about the use of third-party logistics (TPL), including lack of knowledge about a company's internal logistics costs, loss of control and in-house capability, and limited acceptance by workers (Ekeskär and Rudberg 2016).

\section{Logistics Solutions in the Construction Industry}

A logistics solution can include logistics practices to be implemented. For instance, material kitting logistics solution includes JIT delivery practice. Table 1 presents the most common logistics practices in the construction industry and their benefits and requirements, while Figure 1 illustrates the key steps of implementing them based on the requirements of the logistics practices shown in Table 1. Each solution is explained as follows.

How a product is designed can impact the success of the logistics operations (Mather 1992). Logistically friendly product designs would help decrease complexity. Thus, building design for logistic operations in construction phase is added to Table $\mathbf{1}$ as a logistics practice. A TPL could be utilized at an early phase in construction projects to plan the site layout and logistics to facilitate operations (Skjelbred et al., 2015). Logistics provider could be involved in the design phase, and together with the main contractor, design the logistics routes or openings in the building for better logistic operations in the construction phase. For projects with space limitations, for example a construction project in a city center, planning the layout carefully for logistics purposes would ease the operations at later stages of construction. Since this concept may require use of TPL and temporary storage, the additional implementation cost is considered high at first. More quantitative research is needed to clarify the benefits.

Buffer management, which companies often use to manage uncertainty, prevents time from being wasted while awaiting material deliveries. The requirements for implementing inventory buffers in construction determine the project schedule and reasonable estimations for each activity (Jan and Ho 2006). If the buffer amount is considerably more than the required material amount, the performance may decrease (Horman and Thomas 2005). This can be avoided by accurately scheduling material orders in the project plan at the start of the project (Bertelsen and Koskela 2002).

Just-in-time (JIT) delivery means that materials delivered to the construction site are installed immediately without being stored (Tommelein and Li 1999). JIT delivery can partly decrease the need for on-site storage areas (Jaillon and Poon 2014) and cut cost, eliminate waste (Aghazadeh 2004). Materials have a lower 
TABLE 1 | Logistic practices used in construction, including their requirements and benefits.

\begin{tabular}{|c|c|c|c|c|}
\hline Logistics practice & Benefits & Requirements & $\begin{array}{c}\text { How clear are the } \\
\text { benefits? }\end{array}$ & Implementation costs \\
\hline $\begin{array}{l}\text { Building design for } \\
\text { logistic operations in } \\
\text { construction phase }\end{array}$ & $\begin{array}{l}\text {-Temporary openings and logistic routes } \\
\text { in the building under construction are } \\
\text { considered comprehensively (Skjelbred } \\
\text { et al., 2015) }\end{array}$ & $\begin{array}{l}\text {-Finalizing construction drawings at an } \\
\text { early stage (Skjelbred et al., 2015) } \\
\text {-Logistic professional is involved and } \\
\text { requirements for logistics are known in } \\
\text { the design phase }\end{array}$ & Somewhat clear & High at first \\
\hline Buffer management & $\begin{array}{l}\text {-Less time wasted waiting for material } \\
\text { delivery (Thomas et al., 1989) } \\
\text {-Fewer disruptions to production } \\
\text { (Poshdar et al., 2018) }\end{array}$ & $\begin{array}{l}\text {-Bill of materials (Bradley 2015) } \\
\text {-Activity duration estimations (Jan and } \\
\text { Ho 2006) }\end{array}$ & $\begin{array}{l}\text { Clear (Ballard and Howell } \\
\text { 1994) }\end{array}$ & $\begin{array}{l}\text { Medium (storage, insurance } \\
\text { costs, etc.) Bamana et al. } \\
\text { (2019) }\end{array}$ \\
\hline JIT delivery & $\begin{array}{l}\text {-Decreased on-site storage (Jaillon and } \\
\text { Poon 2014) } \\
\text {-Increased time efficiency (Ballard and } \\
\text { Howell 1995) }\end{array}$ & $\begin{array}{l}\text {-Pull signaling (Davies 1989) } \\
\text {-Right materials at the right time and in } \\
\text { the right amount (Tommelein and Li } \\
\text { 1999) } \\
\text {-Communication between project } \\
\text { management and material suppliers } \\
\text { (Lieb et al., 1988) }\end{array}$ & $\begin{array}{l}\text { Clear (Pheng and Hui } \\
\text { 1999) }\end{array}$ & Medium \\
\hline Consolidation centers & $\begin{array}{l}\text {-Lower inventory costs (Hamzeh et al., } \\
\text { 2007) } \\
\text {-Information transparency during } \\
\text { material flow (Peker et al., 2016) }\end{array}$ & $\begin{array}{l}\text {-Predetermined project schedule (Song } \\
\text { et al., 2008) } \\
\text {-Work location (Song et al., 2008) } \\
\text {-Transportation information, updated } \\
\text { traffic information (Song et al., 2008) }\end{array}$ & $\begin{array}{l}\text { Somewhat clear (Hamzeh } \\
\text { et al., 2007) }\end{array}$ & Medium \\
\hline Material kitting & $\begin{array}{l}\text {-Labor performance improvement (Tetik } \\
\text { et al., 2020) } \\
\text {-Workplace utilization rate increase } \\
\text { (Tetik et al., 2018) }\end{array}$ & $\begin{array}{l}\text {-Complete bill of materials (BOM) (Tetik } \\
\text { et al., 2020) } \\
\text {-Early planning of schedule (Tetik et al., } \\
\text { 2018) } \\
\text {-Identification of parts, material type, } \\
\text { quantity, unit, supplier, kitting date, } \\
\text { delivery date, kit (name/number), task, } \\
\text { and location where the kit will be used } \\
\text { (Zheng et al., 2020) }\end{array}$ & $\begin{array}{l}\text { Somewhat clear; more } \\
\text { research needed (Tetik } \\
\text { et al., 2020) }\end{array}$ & High \\
\hline Takt production & $\begin{array}{l}\text {-Reduced completion time (Vatne and } \\
\text { Drevland 2016) } \\
\text {-Decreased project cost (Vatne and } \\
\text { Drevland 2016) }\end{array}$ & $\begin{array}{l}\text {-Order of the activities (trades) (Vatne } \\
\text { and Drevland 2016) } \\
\text {-Determined takt areas and takt time } \\
\text { (Frandson et al., 2015) }\end{array}$ & $\begin{array}{l}\text { Clear (Vatne and Drevland } \\
\text { 2016) }\end{array}$ & Medium \\
\hline VMI & $\begin{array}{l}\text {-Low vendor demand variability (Huynh } \\
\text { and Pan 2015) } \\
\text {-Reduced inventory (Yao and Dresner } \\
\text { 2008) } \\
\text { - } \\
\text { - }\end{array}$ & $\begin{array}{l}\text {-Contractors' specific material } \\
\text { consumption information records (real- } \\
\text { time inventory management system) } \\
\text { (Holmström 1998) or kanban cards (pull } \\
\text { signals) } \\
\text {-Material information (Holmström 1998) } \\
\text {-Defined reorder levels (Vigtil 2007) } \\
\text {-Defined minimum delivery quantities } \\
\text { (Tanskanen et al., 2009) } \\
\text {-Electronic data interchange (EDI) } \\
\text { (Marques et al., 2010) }\end{array}$ & Clear (Tat et al., 2013) & High \\
\hline TPL & $\begin{array}{l}\text {-Possibility to outsource all logistics } \\
\text { activity (Bask 2001) } \\
\text {-Cost reductions (Linden and } \\
\text { Josephson 2013) } \\
\text {-Reduced time on material handling } \\
\text { (Ekeskär 2016) }\end{array}$ & $\begin{array}{l}\text {-Assessment of the needs determined in } \\
\text { the contract (Wagner and Sutter 2012) } \\
\text {-Clear communication through supply } \\
\text { chain (Janne and Rudberg 2020) } \\
\text { - }\end{array}$ & $\begin{array}{l}\text { Somewhat clear (Ekeskär } \\
\text { and Rudberg 2016) }\end{array}$ & High at first \\
\hline
\end{tabular}


TABLE 1 | (Continued) Logistic practices used in construction, including their requirements and benefits.

\begin{tabular}{|c|c|c|c|c|}
\hline Logistics practice & Benefits & Requirements & $\begin{array}{c}\text { How clear are the } \\
\text { benefits? }\end{array}$ & Implementation costs \\
\hline Material tracking & $\begin{array}{l}\text {-Material visibility (Song et al., 2006) } \\
\text {-Less loss of materials (Ala-Risku and } \\
\text { Kärkkäinen 2006) } \\
\text { - }\end{array}$ & $\begin{array}{l}\text {-Power or Internet connection (Zhao } \\
\text { et al., 2019b) } \\
\text {-Floor plan (Zhao et al., 2019b) } \\
\text {-Set-up and maintenance of the system } \\
\text { (Zhao et al., 2019b) }\end{array}$ & $\begin{array}{l}\text { Somewhat clear; more } \\
\text { research needed to } \\
\text { develop KPIs (Zhao et al., } \\
\text { 2019a) }\end{array}$ & Medium \\
\hline
\end{tabular}

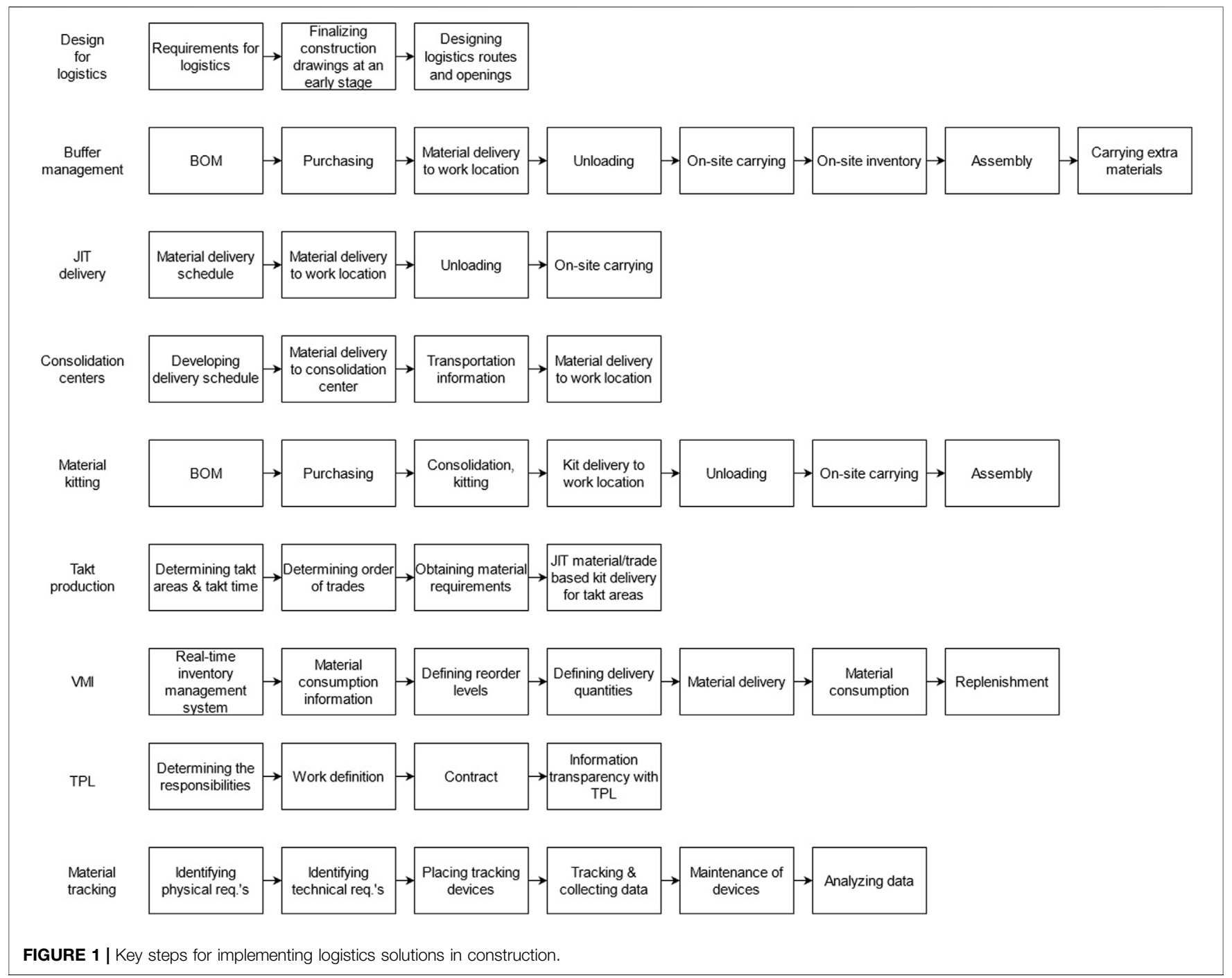

chance of being damaged because on-site waiting times are eliminated. The waste is reduced by delivering the required materials exactly when they are needed. This approach can be applied to both engineer-to-order (ETO) and make-to-stock (MTS) products. The task schedule and specific materials needed in each task must be known in advance in order to implement JIT delivery.
Consolidation centers are solutions for consolidating deliveries from suppliers and producers to location-based or JIT-based coordinated deliveries to a site. Consolidation facilities keep the materials for a certain period until on-site delivery by logistics workers on a JIT basis (Sullivan et al., 2011). Hamzeh et al. (2007) stated that consolidation centers can be used for multiple purposes, such as pre-assembly, kitting (described 
below), consolidation, sorting, and breaking bulks. The requirements for utilizing consolidation centers include the availability of real-time schedule information at the task level, type of shipment, and information on transportation capacity and peak season (Song et al., 2008). The project schedule must be available to ensure the complete pre-planning of material deliveries.

Material kitting packs different parts into a package based on an assembly schedule and supplies these kits to the production (Limère et al., 2012). In kitting, materials are packed according to a specific floor or apartment and are ordered to the site at a precise time period (Riihimäki and Palolahti 2011). This solution connects delivered material batches to site activities in specific locations. To be able to successfully apply the kitting solution, information must be available on the material type, quantity, unit, supplier, kitting date, delivery date, kit (name/number), task, and the location where the kit will be used (Zheng et al., 2020). The benefits of implementing this solution include labor performance improvements and workplace utilization rate increases (Tetik et al., 2018; Tetik et al., 2020). Companies can apply other logistics practices together with kitting solution such as consolidation centers and JIT delivery. Through applying kitting, on-site workers save time by not searching for materials since they are delivered to the task location as presorted kits.

Takt production (derived from the German word Taktzeit, for cycle time) is a lean concept in which users attempt to tune the rate of work output to that of customer demand (Frandson and Tommelein 2014). Its requirements include having an estimated lead time for consuming all materials involved in the planning of material needs and material list calculations (Segerstedt 2017). Ideally, these plans must be made together with the trades involved. The work required for every trade must be completed during the allocated takt beat (Haghsheno et al., 2016). The takt time needs to be determined to implement a takt-based production and determining the takt areas is required to identify the takt time. Capacity buffers and the work density of each team are used when planning with takt (Frandson et al., 2015). Takt-based production brings clear benefits to projects (Binninger et al., 2018), and the necessary know-how to implement this technique is easy to achieve, as are the additional resources for its implementation. The use of takt does require a planning phase during which the takt areas and schedule are determined (Table 1).

Takt results can be improved even more when implemented with specific logistics solutions such as kitting, JIT delivery, and consolidation centers (Tetik et al., 2019). The benefits of takt include reduced completion time and project costs (Vatne and Drevland 2016). More benefits can accrue when the method includes several additional steps, such as explicitly considering material logistics, garbage collection, and real-time data collection (Heinonen and Seppänen 2016).

Vendor-managed inventories (VMI), another logistics solution that can be used in construction projects, is an onsite inventory system in which the material supplier manages the material levels. In a VMI partnership, the supplier makes the main inventory replenishment decisions for the consuming organization and provides continuous replenishment (Marquès et al., 2010). For the practice to work, there must be customerspecific material information records, including reorder levels and minimum delivery quantities (Tanskanen et al., 2015). The system also depends on information technology (IT) platforms, communications technology, and product identification and tracking systems (Waller et al., 1999).

TPL, briefly mentioned earlier, refers to activities carried out by a logistics service provider on behalf of another company. TPL functions can involve inventory management, tracking, secondary assembly operations (Marasco 2008). The use of TPL often leads to more centralized logistics because not all contractors handle their materials themselves. Thus, its use not only outsources but also centralizes activities, which leads to smoother coordination. The ability to work collaboratively with customers determines the future success of TPL providers (Tian et al., 2010). The use of TPL has been shown to reduce construction costs, and the benefits have been shown to exceed the costs of doing the handling in-house (Linden and Josephson 2013).

Tracking materials can be used to improve productivity and decrease material waste. Wi-Fi-based tracking systems can be used to monitor the locations of different construction resources (Woo et al., 2011). Materials can be physically located at the construction site, ready to be assigned on request (Song et al., 2006). Wi-Fi- and Bluetooth-based tracking methods can be used to locate workers to improve their production efficiency and management (Zhao et al., 2017). The same methods may also be used for material tracking. Some of the preconditions to using material tracking include a floor plan to install the tracking devices and ensuring their connectivity and that of power connections and charged batteries (Zhao et al., 2019).

In Table 1, the "How clear are the benefits if invested?" category was chosen based on the National Aeronautics and Space Administration's (NASA) technological readiness assessment scale (Frerking and Beauchamp 2016). Taking this scale as an example, the Clear level means that there is literature about the real application performance of the practice; the application has been widely used in the industry; and information is available on how to use it. The Somewhat clear level means that literature exists on the practice and on testing in simulation environments. The Unclear level means that the industry has not adopted the technology and that further research is needed on the adoption and effects of the practice. The available research identifies the principles underlying the practice. Moreover, implementation costs were identified based on information gathered from the literature.

Table 1 shows that some logistics solutions require more preconditions than others and, therefore, some can be more easily implemented. For instance, buffer management, JIT, and consolidation centers require pull signaling or predetermined and up-to-date project schedules. Material kitting, in contrast, requires detailed product information, such as material type, quantity, unit, supplier, and delivery times, as well as a consolidation center where the materials can be sorted and the kits prepared.

So far, researchers have suggested several logistics solutions that are interdependent of each other, and no framework exists for presenting how construction companies can develop their logistics processes from traditional practices toward more advanced levels. 
TABLE 2 | Previously developed maturity models for concepts relevant to construction logistics and their impacts.

\begin{tabular}{|c|c|c|c|c|}
\hline Model & Purpose & Impacts & Gaps & Levels/themes \\
\hline $\begin{array}{l}\text { Logistics } 4.0 \text { maturity } \\
\text { model }\end{array}$ & $\begin{array}{l}\text { Provides companies with opportunities to } \\
\text { assess current status regarding logistics } 4.0 \\
\text { and develop a road map for improvement } \\
\text { processes (Oleśków-Szłapka and Stachowiak } \\
\text { 2018) }\end{array}$ & $\begin{array}{l}\text {-Increased recognition of the logistics } \\
4.0 \text { concept } \\
\text {-Model can be used to assess } \\
\text { competitiveness in the Polish logistics } \\
\text { sector }\end{array}$ & $\begin{array}{l}\text {-Model is based on the } \\
\text { authors' knowledge and } \\
\text { experience in the field } \\
\text {-Testing/validating with real- } \\
\text { world projects not available }\end{array}$ & $\begin{array}{l}\text {-lgnoring } \\
\text {-Defining } \\
\text {-Adopting } \\
\text {-Managing } \\
\text {-Integrating } \\
\text { Based on: } \\
\text { Management material } \\
\text { and information flow }\end{array}$ \\
\hline $\begin{array}{l}\text { Construction supply } \\
\text { chain maturity model }\end{array}$ & $\begin{array}{l}\text {-Multi-enterprise supply chain maturity model } \\
\text {-Process maturity is achieved in stages by } \\
\text { incrementally controlling and managing the } \\
\text { construction supply chain along the firm, } \\
\text { project, and functional themes (Vaidyanathan } \\
\text { and Howell 2007) }\end{array}$ & $\begin{array}{l}\text {-Provides details on how to adopt the } \\
\text { maturity model from a business process } \\
\text { and value perspective } \\
\text {-Corporate strategy can be aligned with } \\
\text { construction supply chain }\end{array}$ & $\begin{array}{l}\text { Testing/validating with real- } \\
\text { world projects not available }\end{array}$ & $\begin{array}{l}\text {-Ad-hoc } \\
\text {-Defined } \\
\text {-Managed } \\
\text {-Controlled } \\
\text { Based on } \\
\text {-Process (functional, } \\
\text { project, firm) } \\
\text {-Technology } \\
\text {-Strategy } \\
\text {-Value }\end{array}$ \\
\hline $\begin{array}{l}\text { Industry } 4.0 \text { maturity } \\
\text { model }\end{array}$ & $\begin{array}{l}\text { Allows data collection on the state of the } \\
\text { development of manufacturing companies } \\
\text { across different industries and identifies } \\
\text { additional success factors for effective } \\
\text { industry } 4.0 \text { strategies (Schumacher et al., } \\
\text { 2016) }\end{array}$ & $\begin{array}{l}\text {-Nine themes of maturity investigated } \\
\text { using case studies } \\
\text {-Companies can use the results of their } \\
\text { self-assessment }\end{array}$ & $\begin{array}{l}\text { Generic model; domain- } \\
\text { specific maturity models } \\
\text { needed }\end{array}$ & $\begin{array}{l}\text {-Leadership } \\
\text {-Strategy } \\
\text {-Products } \\
\text {-Customers } \\
\text {-Operations } \\
\text {-Culture } \\
\text {-People } \\
\text {-Governance } \\
\text {-Technology }\end{array}$ \\
\hline $\begin{array}{l}\text { Logistics maturity } \\
\text { model for service } \\
\text { companies }\end{array}$ & $\begin{array}{l}\text { Based on three themes: SCOR (supply chain } \\
\text { operations References) model, phases of } \\
\text { industry logistics, and logistics tools } \\
\text { (Werner-Lewandowska and Olejnik 2018) }\end{array}$ & $\begin{array}{l}\text { Logistics maturity levels were } \\
\text { determined individually for each logistics } \\
\text { area (planning maturity, storage } \\
\text { maturity, etc.) }\end{array}$ & $\begin{array}{l}\text {-Open list of logistic tools } \\
\text {-Lack of possibility for an } \\
\text { overall logistics maturity } \\
\text { evaluation of a service } \\
\text { company } \\
\text {-Model is based on the } \\
\text { authors' interpretation and } \\
\text { observations }\end{array}$ & $\begin{array}{l}\text { Six maturity levels } \\
\text { based on } \\
\text {-Plan } \\
\text {-Source } \\
\text {-Inventory } \\
\text {-Distribution } \\
\text {-Return }\end{array}$ \\
\hline
\end{tabular}

The use of maturity models would help in this respect as they build paths from lower levels to more advanced solutions.

\section{Maturity Models to Guide Operations Development}

Maturity models are illustrative of the extent to which practices depend on each other. A common way to build such models is to represent maturity as several cumulative stages, with higher stages building on the requirements of preceding stages (De Bruin et al., 2005). When companies achieve the recommended requirements determined by the maturity model, they can improve the maturity of their processes (Mettler and Rohner 2009). McCormack and Lockamy (2004) demonstrated a correlation between improving process maturity and business performance.

Successful transformation requires different levels (Gökalp et al., 2017). Similarly, the use of logistics maturity levels in construction could help companies gradually increase their business performance. The field needs a roadmap for companies to pursue in order to increase their logistics competence. Determining the maturity levels can help create a guideline for companies to improve their logistics practices and, thus, perform more efficiently in their projects.

Scholars in the project management field have proposed various maturity models, specifically for software development (Paulk 2002) and knowledge management (Seow et al., 2006). These models are applicable for single companies, whereas multicompany supply chains operate in the construction context (Vaidyanathan and Howell 2007). Table 2 provides information on the existing maturity models related to construction logistics, including their impacts and gaps.

The Logistics 4.0 maturity model (Oleśków-Szłapka and Stachowiak 2018) aims to assess companies' Logistics 4.0 status and provide a route for improvement. The model includes five levels: 1) ignoring, 2) defining, 3) adopting, 4) managing, and 5) integrating. Level 1 (ignoring) means that the company is not aware of logistics solutions, while level 5 (integrated) means that it has implemented all possible solutions for improving material information flows. Oleśków-Szłapka and Stachowiak (2018) 
considered three areas of evaluation when defining this maturity model: management, flow of material, and flow of information.

The construction supply chain maturity model (Vaidyanathan and Howell 2007) is a conceptual framework of construction supply chain maturity and involves four levels of maturity: adhoc, defined, managed, and controlled.

The Industry 4.0 maturity model (Schumacher et al., 2016) aims to assess manufacturing enterprises' Industry 4.0 readiness. Company maturity is scored on nine themes: leadership, strategy, products, customers, operations, culture, people, governance, and technology.

The logistics maturity model for service companies (WernerLewandowska and Olejnik 2018) scores a company's maturity in five areas on six levels. The logistics maturity areas are plan, source, inventory, distribution, and return, which the authors determined based on the phases of industry logistics, business activity areas, and the logistics tools used.

These previously developed maturity models provide various concepts for further investigation. The themes for the construction logistics maturity levels were drawn by considering these concepts in the maturity models in the operations and service management field (Vaidyanathan and Howell 2007; Schumacher et al., 2016; Oleśków-Szłapka and Stachowiak 2018; Werner-Lewandowska and Olejnik 2018). The concepts used in these previous studies include planning, source, inventory, distribution, return, phases of industry logistics, logistics tools, process, technology, strategy, value, management, material flow, and information flow.

\section{MATERIALS AND METHODS}

Using the available literature on the logistic practices used in construction and previously developed maturity models relevant to construction, this study first develops a three-stage model for industrial construction logistics. First, previously developed maturity models have been reviewed to determine appropriate themes for construction logistics. Then, based on available literature, logistics practice elements in construction have been determined. After that, a construction logistics maturity model has been proposed. In the next phase, this proposed model is validated in real-life context. Tellis (1997) suggests that single case studies are especially suitable for revelatory cases where an observer may have access to a phenomenon that was previously inaccessible. On the other hand, single case study is often too limited for validation and when research resources are limited, Patton (1990) recommends using a multiple case study approach with purposeful sampling. Therefore, three companies were chosen to validate the proposed model. The companies were selected based on their different size and history of their logistics practices. Furthermore, the fact that the authors had access to reliable data via the selected case companies was a factor in case selection.

The first company (Case 1) is a developer (revenue $976 \mathrm{M} €$, 1,000 employees) whose projects consist of high-rise residential buildings and shopping malls. The company manages logistics by using TPL and a logistics labor provider company. The second company (Case 2) is a medium-sized contractor (revenue
$226 \mathrm{M} €, 302$ employees) with different offerings, including renovations and new residential projects and its own modules, and it manages logistics through a consultant and TPL. The third company (Case 3) is a large main contractor (revenue 679 M€, 2,177 employees) whose projects include large residential and non-residential buildings. A logistics manager plans the logistics operations for the projects, and logistics personnel are always present on-site throughout a project's duration.

Data triangulation is needed to test the validity of the work through the convergence of information from different information sources (Carter et al., 2014). To improve validation, different information resources have been used in this research. The companies' work sites and consolidation centers were observed and secondary data sources, such as company reports, and videos were utilized. Face to face interviews were conducted with the project managers, logistics managers, development coordinators, the site supervisors of the contracting companies, and the material flow engineers of the logistics providers to gain insights into production planning, deliveries, and on-site operations. In total ten interviews were conducted, each lasting about an hour. Interviews included semi-structured questions so the interviewees could answer the questions in a more indepth way.

Three questions to guide the data collection and analysis toward the maturity model were designed:

1. In order to ensure performance improvement, what is the optimal order of logistics practices in each theme?

2. Should companies progress in themes at about the same level to ensure good performance?

3. Do higher maturity levels explain better performance in logistics and projects?

Performance was considered in terms of overall project performance, including schedule, cost, quality, and logistics performance.

\section{MATURITY LEVELS OF CONSTRUCTION LOGISTICS}

Sullivan et al. (2011) note that logistics entails strategic and costeffective storage, material handling, transportation and distribution of resources synchronizing supply chain parties from the origin to the point of use, taking key times/dates into account. Combining the themes from Table 2 and this definition, Table 3 presents the definitions of the relevant logistics themes selected for this study. For a construction activity to be completed, it is necessary to plan the resource requirements (planning). The actors who will conduct the tasks must then be determined (organizing). How the task is done requires knowledge and capability regarding this specific task (operations). To keep all participants up to date regarding the operations, information flow must be fluent (information flow). For the actors to communicate, and for the material flow to be controlled, advanced tools must be used (use of technology). 
TABLE 3 | Logistics themes determined for this study.

Themes

Planning

Organizing

Operations

Information flow

Use of technology

\section{Definition}

Processes for material requirements and delivery planning Assigning actors to specific tasks

Practices regarding performing tasks and how to do so

Practices used in the distribution of information and updates

Tools and technologies used in resources and information distribution

TABLE 4 | Logistics practice elements (listed from low to high in terms of maturity within the themes).

Theme

Logistics practice

Planning

Preplanning of the complete schedule

$\mathrm{BOQ}$ is generated and used in procurement

Planning of material deliveries is complete and final before the start of the project

Material deliveries are planned together with trade partners

Design for logistics, layouts and logistics planning finalized at an early stage

Complete BOM at the task level (created manually)

Complete BOM at the task level (generated automatically, using BIM)

Using BOM in operations such as procurement

Organizing Organizing site deliveries to the site (e.g., logistics calendar)

Responsiveness to the changing requirements of material deliveries

Based on project-specific needs, choosing which parties to do work

Centralized procurement of materials

TPL services used

Separate logistics organization inside the company

Operations Defined material consumption and delivery quantities

Determining who orders/handles missing/broken/extra materials; clear logistics responsibilities determined in contract

Material delivery via JIT

Preassembly and material kitting

Use of technology

Order updates made via phone and email

Smartphone applications used for material orders and deliveries

Work progress tracking connected with logistics process

Material delivery tracking using EDI (electronic data interchange), RFID (radio frequency identification), cloud,

Bluetooth, or Wi-Fi for tracking materials

Material location tracking using EDI, RFID, cloud, Bluetooth, and Wi-Fi for tracking materials

Situational awareness of logistics processes and related work statuses

Digital product data

Information flow

Communication based on one-to-one phone calls and emails

Mobile chat applications are used with written messages

Information transparency with TPL

Information transparency with other actors

Real-time information sharing systems

Integrating other ICT tools into on-site logistics calendar

Automatic order updates and order tracking via special software application

The first step of each logistic solution starts with activities related to planning, such as determining work locations, lists of materials, and delivery schedules. Logistics planning involves the coordination of supply chain and site activities by integrating decision-making and recognizing existing interdependencies to minimize the total material management cost (Sait and El-Rayes 2014). Planning is crucial for the key dates to be aligned.

The organizing theme is key for integrating supply and site decisions. Logistics is related to the distribution of resources and determining the actors and responsibilities that are directly associated with organizing. Organizing means "to form into a coherent unity or functioning whole" or "to arrange by systematic planning and united effort" (Merriam-Webster Dictionary 2020), and integration has been a common theme in previously developed maturity models.

Operations management is critical for an organization to succeed (Slack et al., 2010). Transforming inputs into outputs is the fundamental activity of any production attempt. In a supply chain, all operations are part of a larger supply network where each individual contribution serves customer requirements (Slack et al., 2010). Considering the definition of logistics-which is strategically and cost-effectively conducting the required 
activities from the beginning to the end user-the operations theme is a necessary inclusion in the logistics maturity model.

The synchronization of the various parties involved is possible with proper IT tools and an effective information flow. Inventory, distribution, and return operations must be recorded with proper IT tools to prevent information and material loss. Construction operations and schedules can be visualized and simulated with software programs (Kamat and Martinez 2001). IT tools that can be integrated with other project management systems can ease the planning and tracking of logistics operations. Thus, the information flow and use of technology themes were included in this study.

Table 4 shows the independent logistics practice elements currently being used in the construction industry. These practices were derived from the requirements of logistics solutions (see Table 1 and Figure 1), and were used to develop the maturity model. The planning of material deliveries is required for material kitting, inventory buffers, JIT, and consolidation centers. Thus, the use of a bill of quantities (BOQ) for material procurement enables the implementation of these solutions. In construction, the end product is assembled from several generic and specific components via numerous subcontractors; as such, partnering is required when developing material delivery processes (WegeliusLehtonen and Pahkala 1998). Therefore, a complete bill of materials $(\mathrm{BOM})$ is needed to successfully order the materials and assemble the end product.

At this point, the difference between the BOQ and BOM must be stated. The BOQ is a collection of work descriptions that specify the quantities of various tasks that should be conducted in order to achieve project targets (Martinez-Rojas et al., 2016). The BOQ is used in construction for cost estimating and procuring materials. The BOM is a structured item list where the elements, parts, or components of the product are listed. It is generally used to keep track of information such as the number of parts used in manufacturing the product; the identification of parts, vendors, part manufacturers, and the costs of the parts (Cesarotti et al., 2006). Thus, the BOM includes more specific information than the BOQ. The BOQ is required for procurement and buffer management, while the BOM is required for more complex logistics practices such as material kitting. The BOM is also used for placing the actual order for products. If the BOM is not available, then subcontractor estimates of the amounts necessary for each material related to a task are used.

Problems can occur while integrating quantity information with planning and procurement. Thus, this research has included the ability to 1) have accurate quantity take-off, 2) generate a complete $\mathrm{BOM}$, and 3) utilize this information in planning as components of higher maturity levels. The final logistics practice in the planning theme means that the complete BOM will be used in various subsequent operations. For instance, materials procurement must be done based on the BOM so that orders can consist of accurate numbers and types of materials.

To have a successful project that is completed within schedule, it is required to have smooth material delivery flows (Suutarla 2016). To have a smooth material delivery, responsible trades for each task for material delivery process, from factory/warehouse till the exact material consumption location, should be determined in the contracts.

TPL providers may act as systems integrators in the supply chain by balancing and integrating the supply chain with the construction site (Ekeskär and Rudberg 2020). TPL can be utilized via partnerships that promote the role of TPL as logistics coordinators (Le 2020). A contractor considering to use a TPL should understand the additional value that it can provide: such usage means that the company does not need to consider logistics as an extra cost, and TPL usage will eventually be translated into additional value. To employ TPL, information transparency is required for effective use, and clear responsibilities must be determined in contracts. When a company understands the value that proper logistics management can bring, it may decide to form its own logistics department.

Centralized procurement is listed under the organizing theme. Procuring the required materials determined by the quantity take-off (BOQ) may generate problems. Thus, centralized procurement can be used to have more control over the materials, including their location and availability (McCue and Pitzer, 2000). It can support logistics solutions by allowing materials to be procured centrally and then delivered to the logistics center (Tetik et al., 2019). The use of centralized material procurement and JIT delivery can guarantee that the required materials will be available on-site at the right moment. Construction projects bring together numerous people who are unfamiliar with each other; they must then closely communicate throughout the project since projects typically require various types of knowledge (Martin et al., 2014). These actors must communicate clearly in order to perform on-site operations. Companies can adopt centralized procurement to avoid miscommunication.

Under the use of technology, the overall use of IT is generally recommended to achieve better logistics processes and avoid delays (Ebrahim et al., 2013). The construction coordination process is usually conducted in unstructured ways, such as via telephone and email, which can lead to interruptions and delays (Dallasega et al., 2020). Mobile applications can be used to manage, control, and visualize data scheduling and improve communication (Ratajczak et al., 2017). The use of shared calendars allows project actors to coordinate tasks, such as material deliveries or meetings, in a centralized agenda (Nitithamyong and Skibniewski 2004). Such calendars are significant tools for organizing activities and their corresponding actors. The use of ICT tools as standard on-site logistics management allows room for more developed solutions such as integrating the calendar with other ICT tools (Suutarla 2016).

The technologies required to implement VMI solutions are also listed under the technology theme. To be able to successfully implement VMI, real-time information-sharing systems are required between the supplier and the site storage. The use of electronic data interchange (EDI) also allows rapid data transferal for VMI implementation (Danese 2006). Reorder levels and minimum delivery quantities must be determined to implement VMI (see Table 1 and Figure 1). 
TABLE 5 | Planning maturity.

\begin{tabular}{|c|c|c|c|c|}
\hline Levels $\rightarrow$ & Basic & Managed & Toward integrated & Industrialized \\
\hline Score (1-4) & 1 & 2 & 3 & 4 \\
\hline $\begin{array}{l}\text { Planning } \\
\text { activities } \rightarrow\end{array}$ & $\begin{array}{l}\mathrm{BOQ} \text { is used in } \\
\text { procurement }\end{array}$ & $\begin{array}{l}\text { Material deliveries are planned together with } \\
\text { trade partners }\end{array}$ & $\begin{array}{l}\text { Task level BOM is used in } \\
\text { procurement }\end{array}$ & $\begin{array}{l}\text { Complete BOM-based material } \\
\text { delivery plan }\end{array}$ \\
\hline
\end{tabular}

The tracking of materials and labor enables production control in construction via the use of several technologies, including RFID (Costin et al., 2012), Wi-Fi, and Bluetooth (Zhao et al., 2017). Tracking devices must be procured and installed on the materials, and connectivity solutions are required to establish indoor positioning systems. Depending on the technical system a company chooses, certain installation guidelines must be followed, and the systems must be tested to evaluate tracking accuracy (Zhao et al., 2019). Thus, companies must be willing to invest resources to implement these solutions. Activity tracking requires a medium level of additional investment to be implemented, and the benefits are somewhat clear (see Table 1).

In terms of the information flow theme, different companies may choose to use different tools and systems. The easiest way to communicate with other project actors on the go is through telephone and email, while the best way to avoid information loss is to use written communications. Mobile applications are more user-friendly and can restore information that can then be connected to emails. For this reason, the applications in Table 4 appear at a higher level than reliance on telephone calls. The ordering of the practices in this theme reflects the logical evolution of information flow activities.

\section{THE PROPOSED MATURITY MODEL}

Table 4 which is about the existing logistic practices under the five themes was mainly used for developing the model. For each theme, maturity levels and their corresponding scores are represented. The scores are used for assessing the construction logistics maturity of the case companies for the validation of the model.

Having the BOQ available is considered the basic level for the planning theme. The best practice in terms of planning is where a company generates a complete list of materials for each task and then uses the list in the procurement and material delivery schedule prior to the start of the project. This was considered the industrialized level. To achieve this practice, companies may start with having the BOQ available. Material deliveries should be planned together with project partners. When a complete tasklevel BOM is available, material deliveries can be made with accurate amounts. It is not always possible to automatically generate a $\mathrm{BOM}$ during renovation projects as the BIM on sufficient level of detail may not be available. Companies can achieve a complete BOM during construction projects by having a complete design model at LOD400 before they begin but as stated by Song and Fisher (2020) such models are rare in current practice. Table 5 illustrates the maturity model excerpt for the planning theme.
For the organizing theme, determining which trade will perform which logistics task is the minimum practice for advanced logistics. The main contractor can manage the logistics calendar and share it with the subcontractors. During the planning of a project, organizing which parties are responsible for which logistics practices are crucial for the success of a project. Procuring the materials centrally is considered as a step toward integrated logistics. Having a separate unit responsible for logistics decisions or systematically utilizing the TPL would be best under the organizing theme. Table 6 illustrates the organizing maturity for construction.

Regarding the operations theme (which is closely connected to the planning theme), it is vital to decide on delivery quantities based on material consumption. In the basic level, material consumption amounts are simply scattered throughout a project's subcontractor network; the main contractor does not usually have this information. The responsibilities of who handles material logistics should be determined in the contracts. If a company cannot manage JIT delivery, then the benefits from material kitting cannot be fully realized. Clear logistics responsibilities should be determined in contracts, and JIT delivery, material kitting, and centralized procurement should all be implemented. When the materials are unloaded on-site, they must be moved to their location of usage. Any other material movement would cause inefficiencies (for instance, unnecessary vertical movement of materials between different floors of a building). Thus, minimizing material movement on-site is considered an advanced level for managing on-site logistics in projects. Material kitting and pre-assembly of materials are considered the best case in this theme due to the high information requirement to implement these solutions. Construction operations maturity is depicted in Table 7.

In terms of the use of technology theme, the achievement of BIMlinked digital product data is the best industrialized case. Companies can develop their own material tracking software to increase control over site deliveries, thereby impacting the progress of the on-site work. Smartphone applications which would be used by on-site personnel is considered as the basic case. Table 8 illustrates the maturity levels in terms of use of technology in construction.

The most industrialized logistics practice in terms of the information flow theme was having automatic order updates and order tracking via special software applications, where the progress was tracked on-site and material delivery information is fed to that progress. Real-time information-sharing systems can aid in achieving situational awareness of material deliveries and work progress. The prior steps for achieving this state began from material delivery update systems used by the project participants, real-time information sharing, and integrating those tools into a logistics calendar (which is connected to the organizing theme). Table 9 shows the construction information flow maturity levels. 
TABLE 6 | Organizing maturity.

\begin{tabular}{|c|c|c|c|}
\hline Levels $\rightarrow$ & Basic/Managed & Toward integrated & Advanced \\
\hline Score $(1-3)$ & 1 & 2 & 3 \\
\hline Organizing activities $\rightarrow$ & Organizing logistics work & Centralized procurement & Systematic use of TPL or in-house logistics department \\
\hline
\end{tabular}

TABLE 7 | Operations maturity.

\begin{tabular}{lllll}
\hline Levels $\rightarrow$ & & Basic & Managed & \multicolumn{1}{c}{ Advanced } \\
\hline$(1-4)$ & 1 & 2 & 3 & \\
$\begin{array}{l}\text { Operations } \\
\text { activities } \rightarrow\end{array}$ & Logistics responsibilities & Material consumption and delivery & Systematic minimization of material & Use of JIT delivery, material kitting \\
determined in contract & quantities available & movement on-site
\end{tabular}

TABLE 8 | Use of technology maturity.

\begin{tabular}{|c|c|c|c|c|}
\hline Levels $\rightarrow$ & Basic/Managed & Toward integrated & Advanced & Industrialized \\
\hline Score (1-4) & 1 & 2 & 3 & 4 \\
\hline $\begin{array}{l}\text { Use of technology } \\
\text { activities } \rightarrow\end{array}$ & $\begin{array}{l}\text { Smartphone applications for material orders } \\
\text { and delivery updates }\end{array}$ & $\begin{array}{l}\text { Material delivery and location } \\
\text { tracking systems }\end{array}$ & $\begin{array}{l}\text { Machine-readable digital } \\
\text { product data }\end{array}$ & $\begin{array}{l}\text { BIM-linked digital } \\
\text { product data }\end{array}$ \\
\hline
\end{tabular}

\begin{tabular}{|c|c|c|c|c|c|}
\hline Levels $\rightarrow$ & Basic & Managed & Toward integrated & Integrated & Industrialized \\
\hline Score (1-5) & 1 & 2 & 3 & 4 & 5 \\
\hline $\begin{array}{l}\text { Information flow } \\
\text { activities } \rightarrow\end{array}$ & $\begin{array}{l}\text { Material order and } \\
\text { delivery update } \\
\text { systems }\end{array}$ & $\begin{array}{l}\text { Real-time information } \\
\text { sharing systems }\end{array}$ & $\begin{array}{l}\text { Integrating ICT tools to } \\
\text { shared logistics calendar }\end{array}$ & $\begin{array}{l}\text { Status of logistics integrated to } \\
\text { situational awareness of the } \\
\text { project }\end{array}$ & $\begin{array}{l}\text { Automatic order updates based } \\
\text { on situational awareness }\end{array}$ \\
\hline
\end{tabular}

The maturity model in Figure 2 combines Tables 5-9 and presents the path in each theme: from basic logistics to optimized, industrialized logistics. The elements from basic towards optimized level under one theme in the model do not necessarily have a predecessor-successor relationship. Instead, they also reflect the needed investments and obtained benefits. The intensity of the colors increases when the maturity gets higher. A company can determine its current maturity level by identifying its current operations with the elements of the model and by so, seeing if it is under the basic, advanced or optimized.

The maturity model does have some interdependencies between the items from different themes, as shown via the arrows in Figure 2. The direction of the arrows indicates the direction from the prerequisite. For instance, for centralized procurement (under the organizing theme), a task-level BOM needs to be utilized, which is under the planning theme. Similarly, to be able to integrate a shared logistics calendar with other ICTs such as tracking tools, the company first needs to use the shared logistics calendar. To create a BOQ, material consumption quantities need to be available. The use of realtime information-sharing systems facilitates situational awareness.

\section{VALIDATION OF THE MODEL}

The applicability and substance of the proposed model were validated through three industry case examples. The model was first presented to the development and logistics managers of the case companies. Then, inquiries were made on whether they have been following a similar order of practices presented in the model in their organizations. Based on the collected interview data, the practices of the companies were analyzed to see possible compatibility with the proposed model.

\section{Case 1: Large Developer Company}

Case 1 operates in Estonia, Russia, and Finland. The company works with a specialized logistics service provider as well as a logistics labor provider company. The logistics service provider focuses on material flow, while the labor provider only provides material carrying activities on-site. The logistics practices used in projects are determined by the size and location of the project and client-specific requests. For large and challenging projects, the company implements more sophisticated logistics solutions, such as material kitting and takt production.

The company usually does not have BOM information, and it relies on subcontractors for material information. It tries to 


\section{Logistics maturity in construction}

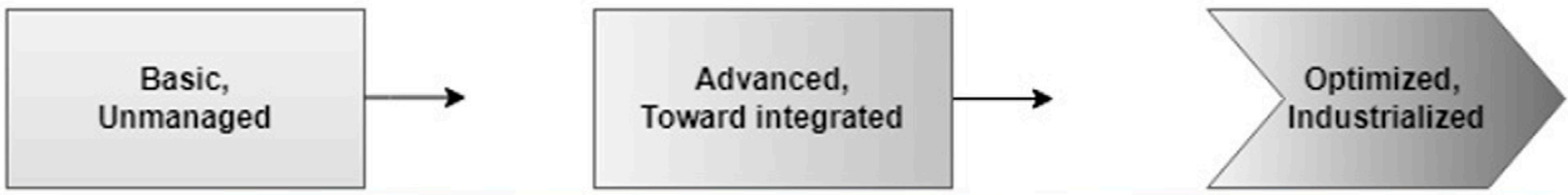

\section{Operations}

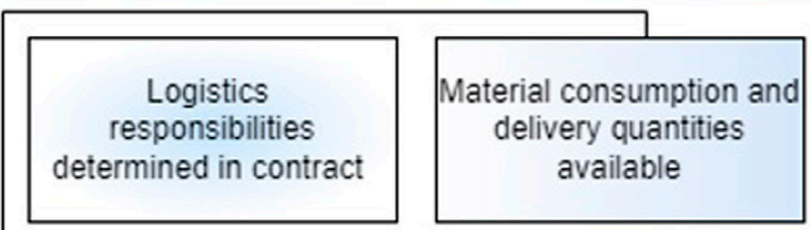

Systematic minimization of material movements on site

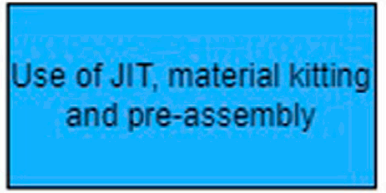

\section{Organizing}
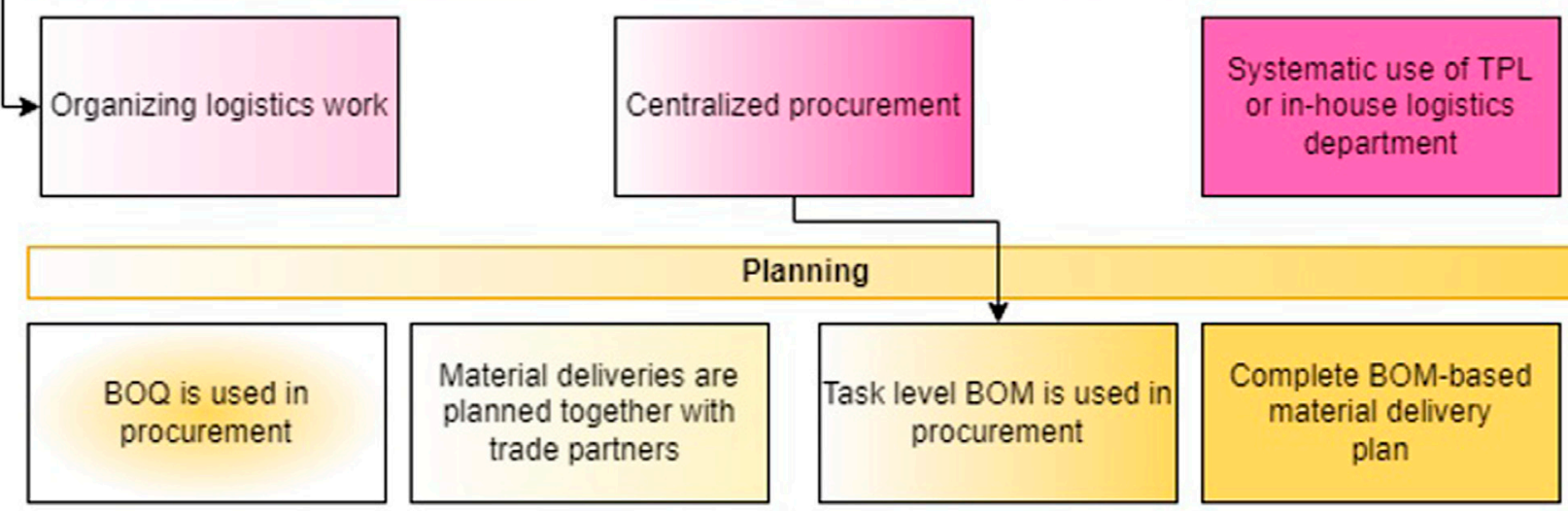

Use of technology

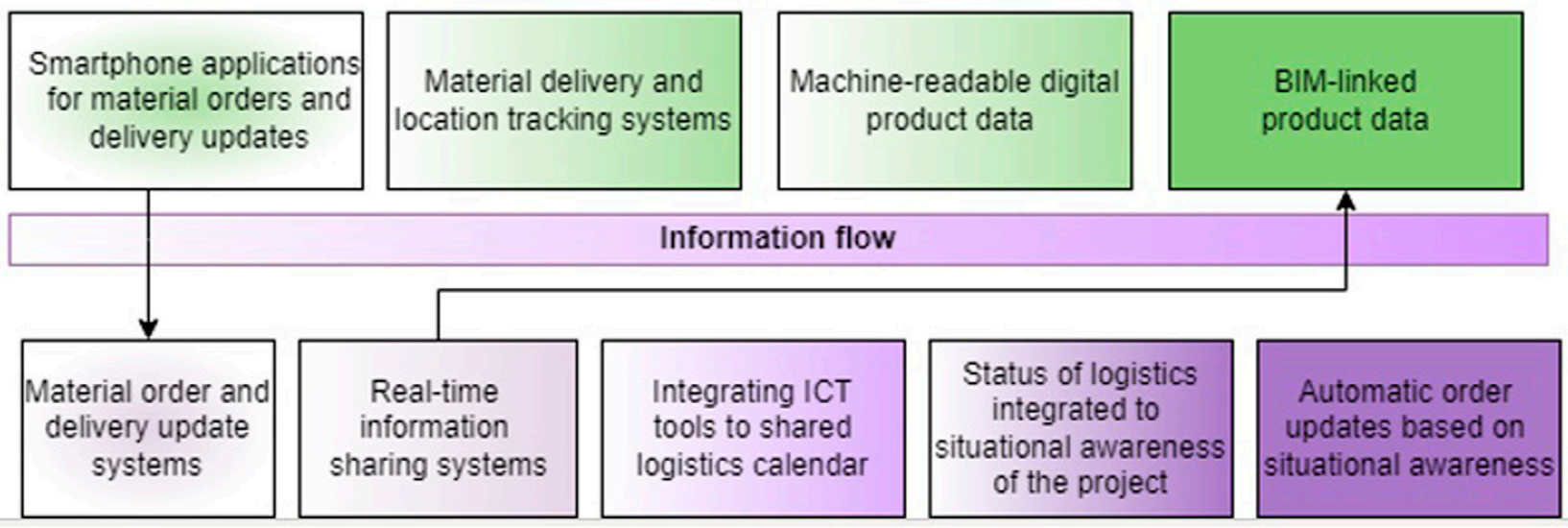

FIGURE 2 | Construction logistics maturity model.

enrich its 3D BIM models to have a more complete BOM and uses a BOQ in procurement. This confirms the best case determined in the model in terms of planning and the case company is trying to reach this level. The company either uses the TPL's logistics applications or a simpler version of a logistics calendar in its projects. It also utilizes an automatized combinatory $3 \mathrm{D}$ model system for model updates. At the time of this study, the company did not engage in material or delivery tracking activities. During a project in which the company used takt production, a consolidation center, and TPL, numerous unnecessary material movements were observed onsite. 


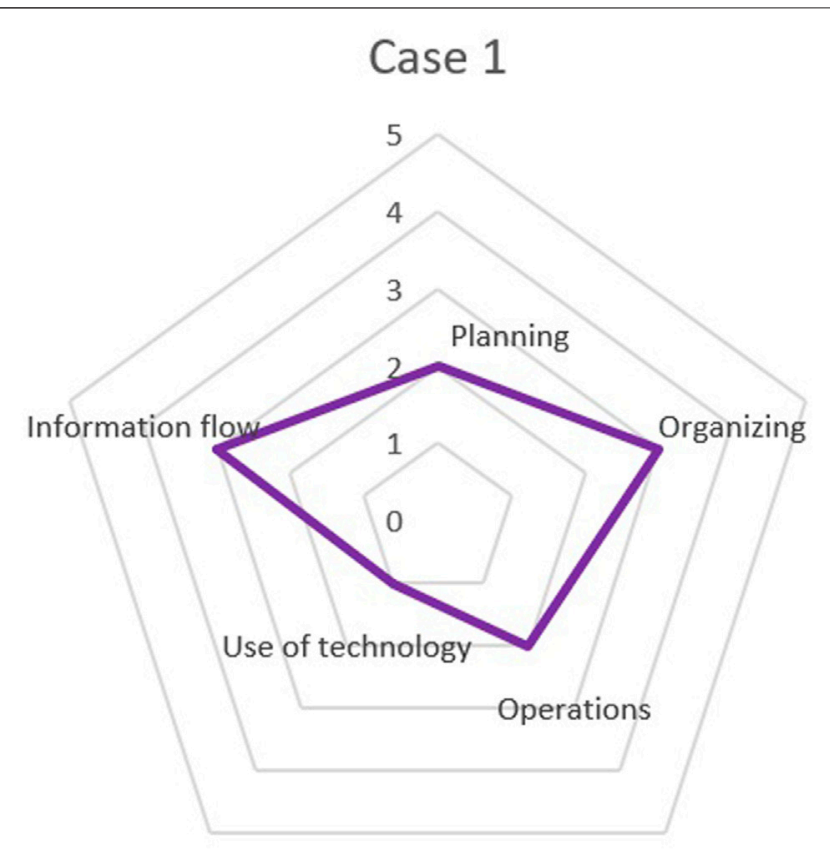

FIGURE 3 | Case 1's logistics maturity assessment.

The most significant lesson from this example was related to avoiding having to move materials on-site multiple times after the material delivery. The root cause of this situation-ordering overly large material buffers-was revealed after interviewing people from a current project, which was caused by not using a BOM at the task level (i.e., not utilizing a BOM in operations, e.g., in procurement). Procuring materials without considering the material needs in a BOM led to the existence of large buffers that then had to be carried back and forth between task locations and inventory. Using a BOM for procurement and, thus, avoiding unnecessary material movements on-site is important for more efficient material logistics and reducing the wasted labor time involved in moving materials unnecessarily.

Another observation from this example was the importance of information transparency with the TPL. Several unscheduled deliveries to the site were noted during the observations onsite, which caused problems in the use of the unloading area as the TPL was not informed about the deliveries. Thus, the material deliveries were not effectively planned with the trade partners. The interviewees mentioned that, because of changing project requirements, they have been trying to have a maximum of 2 weeks of scheduling available at all times. Cooperating properly with the TPL was crucial to avoiding unexpected interruptions in ongoing operations.

All in all, the company confirmed that the order of the logistics practices followed in the developed model: it used a BOQ in procurement; a form of shared logistics calendar was used; and it chose which logistics practices were to be combined in the projects. Figure 3 shows the radar chart for Case 1's maturity levels presenting logistics maturity assessment for this case company. Note that there are only three levels in Organizing theme. There are five levels in information flow.
The rest of the themes have four levels. For planning, the company scores 2 as the TPL arranges the material deliveries with some of the contractors. For the organizing theme, the company is not using centralized procurement. It uses TPL in some projects yet not in a systematical way. Thus, it is considered that it scores 2 for this theme. For Operations it is considered that it scores 2. Case 1 is able to utilize JIT and material kitting for some projects. However, it neither yet systematically minimizes the material movement on site, nor has material consumption information. For use of technology theme Case 1 scores 1 as material delivery tracking systems are not used. In terms of information flow, it was detected that the material deliveries were handled with a special software solution through the TPL that the company used. Thus, Case 1 scores 3 for information flow theme. In the future, they will try to have a complete BOM, available material consumption and delivery quantities, JIT, and material kitting. In general, the company is in the "basic, unmanaged" category and currently plans to move to the "advanced, integrated" category.

\section{Case 2: Medium-Sized Contractor}

The second industry example is a medium-size contractor operating in Finland. At the time of the study, the company had worked for some time with the same logistics provider in its projects and had achieved a centrally coordinated material logistics flow in its previous projects, including TPL coordinating consolidation, JIT delivery, and unloading activities. Because many subcontractors preferred to bring their own materials to the site or consolidation centers, the company was not yet using centralized procurement. In general, communication issues can occur in the use of unloading areas when subcontractors handle their own materials, including unscheduled deliveries by subcontractors.

The company recognized the importance of logistics. It pioneered the material kitting practice with TPL in renovation projects in 2018 (Tetik et al., 2018). Due to this, Case 1 scores 4 in operations theme. Previous research on case projects from the company found that the use of kitting had stabilized assembly work and increased workplace utilization rates and on-site labor productivity (Tetik et al., 2020). It was able to have a complete delivery schedule during a previous pipe-renovation project where most of the materials were delivered as kits, which the company achieved by planning together with its project partners and then following the plan. Today, the company does not see much value in using the practice for small residential renovation projects as doing so would require extensive planning, and unexpected events can occur due to demolition in renovation projects.

At the time of the study, the company was also using takt production in its projects, and TPL had piloted material tracking activities using RFID tags to track material deliveries. Since the TPL provider is systematically used, the company scores 3 in organizing theme. Note that there are only 3 levels in organizing. Subcontractors created a BOM during the planning phase, and the company had tried to create a standard list of work orders to have a generic BOM; it would then modify the BOM based on customer-specific requirements. Since the subcontractors have 


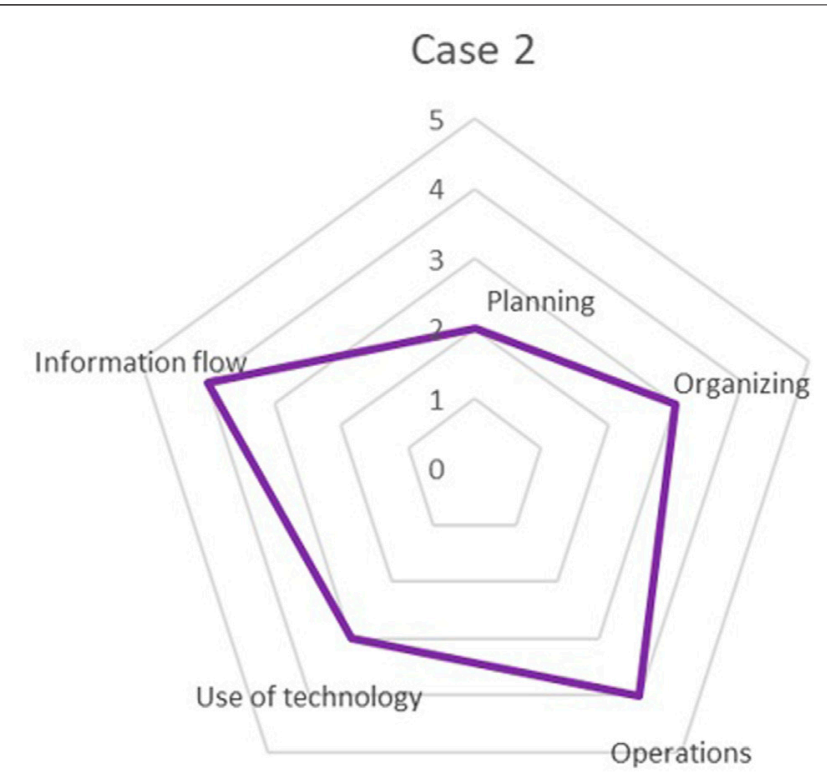

FIGURE 4 | Case 2's logistics maturity assessment.

the $\mathrm{BOM}$ and not the main contractor, the company scores 2 in planning theme. The company used its own application for tracking work progress, although not all site personnel used it effectively. Since it is a medium-size and fairly young company, it is relatively agile and innovative. At the time of the study, the company had experimented with new ways of conducting operations, such as by developing and using its own software applications. Currently, it is taking steps to develop a digital takt production application for monitoring and supporting schedule planning and construction progress. Thus, the company scores 4 in information flow. The most significant observation from this case is the effect of the size of its projects (which affects which logistics solutions will be used) and the fact that the logistics solutions that it had pioneered could be discontinued for small renovation projects. Figure 4 shows the radar chart for Case 2's maturity levels. In general, the company can be regarded as being in the advanced, toward integrated level as current practices mostly fall into this level based on the maturity model (present steps include material delivery tracking, advanced material kitting, complete material delivery schedule, attempts at real-time information-sharing systems, systematic use of TPL).

\section{Case 3: Large Nordic Contractor}

The third example is a large international contractor operating in Europe and the United States, although this study only investigated its operations in Finland. The company provides construction and equipment services and residential project development. It values logistics operations (it has had a logistics manager for 13 years) and attempts to have its own logistics maturity model. It has piloted all the logistics practices mentioned in Table 4, except for material kitting, which it plans to implement in the near future, along with takt production in the interior phase. While the necessary materials are known before

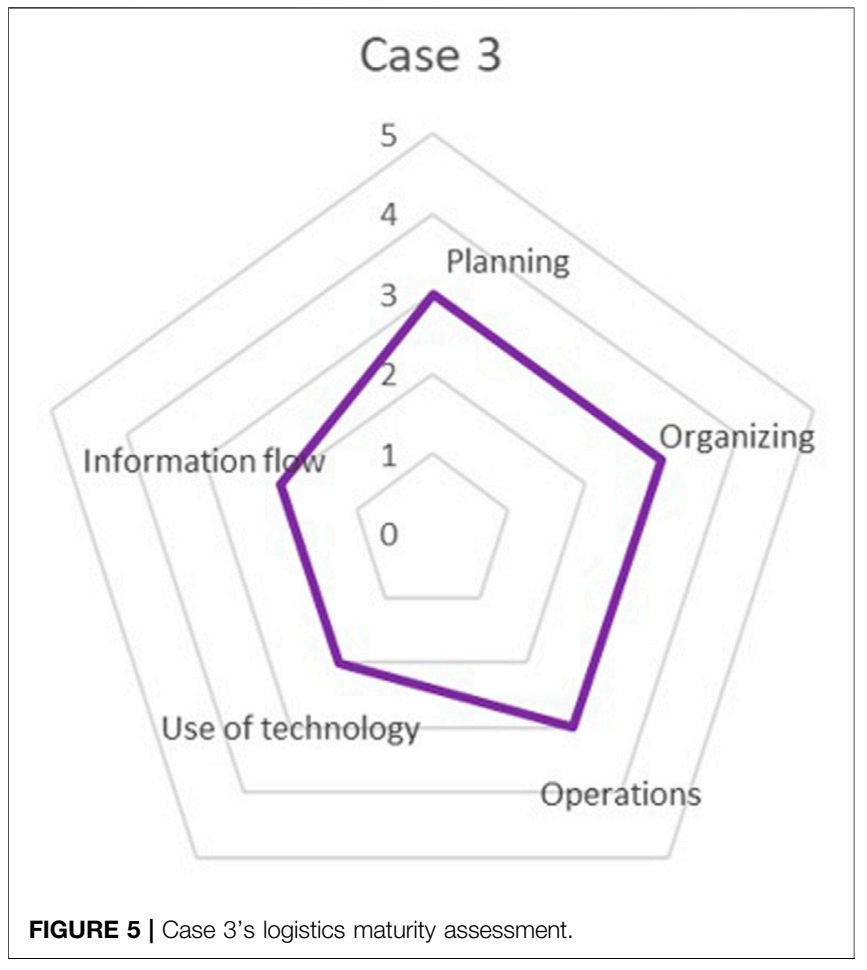

construction starts, when exactly will these materials be needed on-site remains unknown.

The company uses a logistics handbook in every project that includes guidelines and best practices. Clear responsibilities are determined in its contracts with subcontractors. The logistics practices intended for each project are determined based on project-specific needs and conditions. For instance, if the project is large, nonresidential, located inside the city, and is up against a tight schedule, then the company uses all possible solutions. It does not use TPL but does have its own logistics manager, and it hires a logistics supervisor for every project.

The company pioneered the use of VMI in the Finnish construction industry. Floor-specific JIT deliveries are used during the structural phase of every project, with a crane lifting the materials in the structural phase before the envelope is closed. Apart from these differences, the company follows the logical order of the logistics practice elements shown in Table 4. A whole procurement plan is based on the BOQ. In some cases, central procurement is used if the subcontractors perform only the assembly operations and do not bring their own materials. Due to using task-level BOM, Case 2 scores 3 in planning theme. It scores 3 in operations theme as material kitting and preassembly have not been used by the company yet. How the BIM is utilized depends on the quality and level of detail (LOD) of the model. The company has an initiative to develop an advanced software tool for monitoring real-time takt schedules and sharing schedule performance information between management and employees.

It evaluated the benefits of the various logistics solutions used and decided that the practices were worth implementing due to 
the resulting savings in costs and time. The problems the company still encounters include incorrectly delivered materials, late or early deliveries, and inappropriate equipment. In addition, the subcontractor may think that every site has a forklift, even if projects normally only have a tower crane, meaning that delivery trucks need to be opened from the top to be unloaded. The company uses logistics calendars and telephone calls to organize material deliveries. Some elements are tracked in real time, from the design phase through to the assembly, and these status data are then compared to the plan. A digital web-based logistics calendar was used in its projects. The company also tried to keep the movement of materials on-site to an absolute minimum. In general, the company is in the advanced, toward integrated level and is approaching the optimized, industrialized level. Figure 5 shows the radar chart for Case 3's maturity levels. Since the company has its own logistics unit, it scores 3 in organizing theme. It scores 2 for information flow and use of technology themes.

The most significant observation from this company was that it chose to be competent in utilizing many logistics solutions. Based on project-specific needs, it combined the most suitable logistics practices from its repertoire. Its managers considered that having a wide range of logistics capabilities was important to be able to respond efficiently to a project's unique needs. In the interviews managers of the company confirmed that the order of the logistics activities presented in the model is logical and they have mostly followed it in their operations.

\section{EVALUATION OF THE MATURITY MODEL: ANSWERING THE GUIDING QUESTIONS}

For an optimal order of logistics practices, the companies began their efforts toward better logistics by having a fruitful planning phase in which they tried to make the schedule available and complete the BOQ. The companies decided on the logistics practice elements to be implemented based on project-specific conditions, such as the size of the project, the physical conditions of the site, and the distance to the city center. The first logistics practice that Case 3 ever implemented was VMI, meaning that project-specific conditions played a significant role. As such, companies may choose not to follow the logical order stated in this study.

The analysis indicated that the most important themes were planning followed by organizing. Every project started with the planning phase, with the companies putting a great deal of effort into this phase. Based on the industry examples, the work did not progress well unless the project and material delivery schedule for the subsequent 2 weeks were available. It was noted that it was vital to determine which project party was responsible for which tasks. Use of technology and information flow were found to be supporting themes. Thus, every theme does not need to occur at the same level. That is why there are no strict lines between basic, advanced and optimized levels as progress in every theme can be at a different pace. Moreover, a company can be in between two consecutive maturity levels under one theme. While planning was the most important, even with adequate planning, on-site problems could still occur due to the ongoing culture of a construction site. Based on the industry examples, companies could still regard situations as common occurrences if, for example, some of the labor force does not show up on schedule or if, even though there is no on-site storage, a month's worth of materials are unloaded on-site unscheduled.

The company interviewees mentioned that they still use the logistics practices they had used because they were worth implementing. For instance, Case 3 had long used a form of kitting in the structural phase because it increased the company's logistics performance. Similarly, Case 1 considered decreasing unnecessary material movements on-site by adjusting the buffer amount. Information on the level of financial gain from the practices was confidential. Thus, this study concludes that continuing to employ the practices meant that better performance was achieved.

\section{DISCUSSION}

The key outcome of this study is the proposed and empirically validated logistics maturity model for the construction industry. The developed maturity model consists of five themes: planning, organizing, operations, technology, and information flow. In addition to the maturities in these logistics themes, the paper illustrated the interdependencies between the themes. Previously developed logistics maturity models were not domain-specific, were based on authors' opinions, and lacked overall maturity evaluation. Building on previously developed maturity models in the logistics field, the model developed in this research was based on similar themes, although it focused more on themes that are of relevance to construction logistics, such as planning, organizing, operations, use of technology and information flow.

This research indicated that material consumption and delivery quantities are important resources that the case companies could tap into. The case analyses showed that unnecessary material movements on-site should be avoided by having only the proper amounts of material buffers onsite. Based on industry examples avoiding unnecessary material movements on-site, except for the initial unloading and later movement of the materials to the exact work location must be achieved. This is in line with those of previous studies in the literature on avoiding having to move materials several times on-site after unloading (e.g., Elfving et al., 2010). A BOM must be available and utilized during operations to determine adequate buffer amounts. Thus, detailed level information on material consumption is key for success in many logistics practices.

This research showed that advanced logistics operations may only be conducted based on a complete design model-more specifically, a complete BOM. Design models should have an adequate LOD to be able to have a BOQ and BOM (Mousharbash 2020). An increased LOD in design models could open up possibilities for digital product data 
linked to BIM. Exerting effort under the use of technology and planning themes associated with increased LOD in the design models and a complete BOM can lead to the use of accurate models that leave no room for improvisation. The use of a BIM model with a high LOD completed prior to the start of the project may enable the utilization of the design model in subsequent operations, thereby aligning with industrialized construction practices such as Direct Digital Construction (DDC) (Tetik et al., 2019). DDC is an operations management practice that entails the use of a complete digital design model over a building's lifecycle to prevent improvisations and improve the reusability and automation of designs and processes across projects. The present research indicates that the use of advanced and industrialized logistics processes could be a crucial step toward digital operations at the whole-project level. Finalizing the site layout at an early stage of the planning of a construction project, such as in design for logistics, is also parallel to DDC concept (Tetik et al., 2019).

The practical implications of this study include the requirements for maturity levels that will provide a roadmap for companies. Assessing a company's logistics maturity can help it obtain more information about the correlation between its maturity and its competitive position, size, and the level of internationalization of its operations (Oleśków-Szłapka and Stachowiak 2018). Companies can choose where to excel and which logistics practices to use based on project-specific needs. Being able to implement the different logistics practices is the key to responding to different project needs and ensuring optimized project performance. Larger companies that take over different kinds of projects may lose focus on which practices to invest in, while smaller companies might be able to limit their scope in terms of which kinds of projects they undertake and by specializing in relevant logistics practices.

\section{CONCLUSION}

In this study, a logistics maturity model for the construction industry has been developed. Regardless of the locations and markets in which companies operate, they may assess their own logistics maturity and improve their maturity levels by using the model developed in this study. Various logistics practices that can be used in construction projects were reviewed as well as exploring their benefits and requirements. The model was developed based on the

\section{REFERENCES}

Aghazadeh, S. M. (2004). Does Manufacturing Need to Make JIT Delivery Work? Manage. Res. News.

Ala-Risku, T., and Kärkkäinen, M. (2006). Material Delivery Problems in Construction Projects: A Possible Solution. Int. J. Prod. Econ. 104 (1), 19-29. doi:10.1016/j.ijpe.2004.12.027

Arbulu, R., and Ballard, G. (2004). Lean Supply Systems in Construction. Procs 12th IGLC Denmark. literature, and company examples were used to validate it. The model includes the best practices and the intermediate steps to reach them.

During the observations of the three companies, each with varying backgrounds and logistics models, it was noted that the companies were finally valuing logistics and that they no longer viewed logistics as merely the delivery and carrying of materials. The use of logistics is vital in terms of construction production. In the future, overall reliability in the construction supply chain as well as the flow of on-site operations could be remarkably improved by increased logistics maturity.

This research and the proposed model do have certain limitations. The study was limited to analyzing the practices of a limited number of companies. Researchers should apply the model to additional companies with different project and operation types to further elaborate on its validity. The proposed model does not include companies' contextual settings, specific requirements, or business targets, and a company could well have valid reasons for not following it in all of its projects. As the company managers articulated, the size of a project, the distance to the city center, and client preferences all influence the selection of which logistics practices the company will implement in each project. Future research should evaluate the proposed maturity model for different project contexts and reflect on the logistics evolution of further case studies that employ this model. One possible direction is to utilize an operational research approach to analyze the companies' decision making regarding the development of their logistic solutions.

\section{DATA AVAILABILITY STATEMENT}

The raw data supporting the conclusions of this article will be made available by the authors, without undue reservation.

\section{AUTHOR CONTRIBUTIONS}

Conceptualization MT, AP; methodology MT; draft preparation MT, AP; review and editing MT, AP, OS, JH; supervision AP, OS, JH.

\section{ACKNOWLEDGMENTS}

We would like to acknowledge Aalto School of Engineering for providing funding during the preparation of this article.

Ballard, G., and Howell, G. (1994). "Implementing Lean Construction: Stabilizing Workflow," in Proc., the 2nd Annual Conference of International Group for Lean Construction, 105-114. Ballard, G., and Howell, G. (1995). Toward Construction JIT. Lean construction 291, 300. Barthorpe, S., Robbins, S., and Sullivan, G. (2010). Managing Construction Logistics. Hoboken, NJ, USA: Wiley-Blackwell, 20-49.

Bask, A. H. (2001). Relationships Among TPL Providers and Members of Supply Chains-A Strategic Perspective. J. Business Ind. Marketing.

Bell, L. C., and Stukhart, G. (1987). Costs and Benefits of Materials Management Systems. J. Construction Eng. Manage. 113 (2), 222-234. doi:10.1061/(asce) 0733-9364(1987)113:2(222) 
Berawi, M. A., Berawi, A. R. B., and Hadwart, K. A. (2012). Managing Construction Logistics Management: Findings from Construction Contractors and Industrialized Building System (IBS) Manufacturers. Afr. J. Business Manage. 6 (5), 1932-1944.

Berndt, J. O. (2011). "Self-organizing Logistics Process Control: an Agent-Based Approach," in International Conference on Agents and Artificial Intelligence (Berlin: Springer), 397-412.

Bertelsen, S., and Koskela, L. (2002). Managing the Three Aspects of Production in Construction. Gramado, Brazil: IGLC-10.

Binninger, M., Dlouhy, J., Müller, M., Schattmann, M., and Haghsheno, S. (2018). "Short Takt Time in Construction - a Practical Study," in 26th IGLC, 18-20 Jul 2018 (Chennai: India), 1133-1143.

Bradley, J. R. (2015). "An Evaluation of Capacity and Inventory Buffers as Mitigation for Catastrophic Supply Chain Disruptions," in Global Supply Chain Security (New York, NY: Springer), 99-116. doi:10.1007/978-1-4939-2178-2_7

Büchmann-Slorup, R. (2014). Applying Critical Chain Buffer Management Theory in Location-Based Management. Construction Manage. Econ. 32 (6), 506-519. doi:10.1080/01446193.2013.797094

Carter, N., Bryant-Lukosius, D., DiCenso, A., Blythe, J., and Neville, A. J. (2014). The Use of Triangulation in Qualitative Research. Oncol. Nurs. Forum 41 (5), 545-547. doi:10.1188/14.ONF.545-547

Cesarotti, W. A., Larkin, E., and Topolovac, M. (2006). Method, Apparatus, and Product to Associate Computer Aided Design Data and Bill of Materials Data. Foster City, California, USA: Arena Solutions Inc. U.S. Patent 6,999,965.

Cheng, C. P., and Kumar, S. (2015). "A BIM-Based Framework for Material Logistics Planning," in Proc. 23rd Ann. Conf. of the Int'l, July 29-31 (Perth, Australia: Group for Lean Construction), 33-42.

Cooke-Davies, T. J. (2004). Measurement of Organisation Maturity: What Are the Relevant Questions about Maturity and Metrics for a Project-Based Organisation to Ask and what Do These Imply for Project Management Research? J. Innovations-Project Manage. Res. 2004, 1-19.

Costin, A., Pradhananga, N., and Teizer, J. (2012). Leveraging Passive RFID Technology for Construction Resource Field Mobility and Status Monitoring in a High-Rise Renovation Project. Automation in Construction 24, 1-15. doi:10.1016/j.autcon.2012.02.015

Dallasega, P., Marengo, E., and Revolti, A. (2020). Strengths and Shortcomings of Methodologies for Production Planning and Control of Construction Projects: a Systematic Literature Review and Future Perspectives. Prod. Plann. Control. 6, 1-26. doi:10.1080/09537287.2020.1725170

Dallasega, P., Marcher, C., Marengo, E., Rauch, E., Matt, D. T., and Nutt, W. (2016). "A Decentralized and Pull-Based Control Loop for On-Demand Delivery in ETO Construction Supply Chains," in Procs of IGLC.

Danese, P. (2006). The Extended VMI for Coordinating the Whole Supply Network. J. Manufacturing Technol. Manage. doi:10.1108/17410380610688223

Davies, S. F. (1989). Strategies for Implementing the Just in Time Manufacturing Concepts. Ind. Manufacturing Syst. Eng.

De Bruin, T., Freeze, R., Kaulkarni, U., and Rosemann, M. (2005). Understanding the Main Phases of Developing a Maturity Assessment Model.

Ebrahim, K., Irizarry, J., and Jalaei, F. (2013). Integrating BIM and GIS to Improve the Visual Monitoring of Construction Supply Chain Management. Automation in Construction 31, 241-254.

Ekeskär, A. (2016). Exploring Third-Party Logistics and Partnering in Construction: A Supply Chain Management Perspective (Vol. 1753). Linköping: Linköping University Electronic Press.

Ekeskär, A., and Rudberg, M. (2020). Third-Party Logistics in Construction: Perspectives from Suppliers and Transport Service Providers. Prod. Plann. Control (Print). doi:10.1080/09537287.2020.1837932

Ekeskär, A., and Rudberg, M. (2016). Third-party Logistics in Construction: the Case of a Large Hospital Project. Construction Manage. Econ. 34 (3), 174-191. doi:10.1080/01446193.2016.1186809

Elbeltagi, E., Hegazy, T., and Eldosouky, A. (2004). Dynamic Layout of Construction Temporary Facilities Considering Safety. J. Constr. Eng. Manage. 130 (4), 534-541. doi:10.1061/(asce)0733-9364(2004)130:4(534)

Elfving, J. A., Ballard, G., and Talvitie, U. (2010). "Standardizing Logistics at the Corporate Level towards Lean Logistics in Construction," in Proc of the 18th Ann. Conf. of the IGLC, Haifa, Israel.

Fadiya, O., Georgakis, P., Chinyio, E., and Nwagboso, C. (2015). Decisionmaking Framework for Selecting ICT-Based Construction Logistics
Systems. J. Eng. Des. Technol. 13 (2), 260-281. doi:10.1061/(asce)07339364(2004)130:4(534)

Fang, X., So, K. C., and Wang, Y. (2008). Component Procurement Strategies in Decentralized Assemble-To-Order Systems with Time-dependent Pricing. Manage. Sci. 54 (12), 1997-2011. doi:10.1287/mnsc.1080.0934

Fearne, A., and Fowler, N. (2006). Efficiency versus Effectiveness in Construction Supply Chains: the Dangers of "Lean" Thinking in Isolation. Supply chain Manag. Int. J. doi:10.1108/13598540610671725

Flyvbjerg, B. (2006). Five Misunderstandings about Case-Study Research. Qual. Inq. 12 (2), 219-245. doi:10.1177/1077800405284363

Frandson, A. G., Seppänen, O., and Tommelein, I. D. (2015). "Comparison between Location Based Management and Takt Time Planning," in 23rd IGLC (Perth: IGLC), 28-31.

Frandson, A., and Tommelein, I. D. (2014). "Development of a Takt-Time Plan: A Case Study," in Construction Research Congress 2014: Construction in a Global Network, 1646-1655. doi:10.1061/9780784413517.168

Frerking, M. A., and Beauchamp, P. M. (2016). "JPL Technology Readiness Assessment Guideline," in 2016 IEEE Aerospace Conference (Big Sky, MT, USA: IEEE), 1-10. doi:10.1109/aero.2016.7500924

Gökalp, E., Şener, U., and Eren, P. E. (2017). "Development of an Assessment Model for Industry 4.0: Industry 4.0-MM," in Int. Conf. on Software Process Improvement and Capability Determination (Cham: Springer), 128-142. doi:10.1007/978-3-319-67383-7_10

Haghsheno, S., Binninger, M., Dlouhy, J., and Sterlike, S. (2016). "History and Theoretical Foundations of Takt Planning and Takt Control," in Proceedings of the 24th IGLC, Boston, MA, USA, 20-22.

Hamzeh, F. R., Tommelein, I. D., Ballard, G., and Kaminsky, P. (2007). Logistics Centers to Support Project-Based Production in the Construction Industry. Procs of the 15th IGLC 2007, 181-191.

Holmström, J. (1998). Business Process Innovation in the Supply Chain-A Case Study of Implementing Vendor Managed Inventory. Eur. jour. purchasing Supply Manage. 4 (2-3), 127. doi:10.1016/s0969-7012(97)00028-2

Hopp, W. J., and Spearman, M. L. (2004). To Pull or Not to Pull: what Is the Question? M\&SOM 6 (2), 133-148. doi:10.1287/msom.1030.0028

Horman, M. J., and Thomas, H. R. (2005). Role of Inventory Buffers in Construction Labor Performance. J. Constr. Eng. Manage. 131 (7), 834-843. doi:10.1061/(asce)0733-9364(2005)131:7(834)

Huynh, C. H., and Pan, W. (2015). Operational Strategies for Supplier and Retailer with Risk Preference under VMI Contract. Int. J. Prod. Econ. 169, 413-421. doi:10.1016/j.ijpe.2015.07.026

Jaillon, L., and Poon, C. S. (2014). Life Cycle Design and Prefabrication in Buildings: A Review and Case Studies in Hong Kong. Automation in Construction 39, 195-202. doi:10.1016/j.autcon.2013.09.006

Jain, A., Jain, P. K., Chan, F. T. S., and Singh, S. (2013). A Review on Manufacturing Flexibility. Int. J. Prod. Res. 5119, 5946-5970. doi:10.1080/ 00207543.2013.824627

Jan, S. H., and Ho, S. P. (2006). "Construction Project Buffer Management in Scheduling Planning and Control," in 2006 Proc. of 23rd Int. Symp. on Robotics and Automation in Construction, 858-863. doi:10.22260/isarc2006/0158

Janné, M. (2018). Construction Logistics Solutions in Urban Areas (Vol. 1806). Linköping: Linköping University Electronic Press.

Janné, M., and Rudberg, M. (2020). Effects of Employing Third-Party Logistics Arrangements in Construction Projects. Prod. Plann. Control. 2020, 1-13. doi:10.1080/09537287.2020.1821925

Kamat, V. R., and Martinez, J. C. (2001). Visualizing Simulated Construction Operations in 3D. J. Comput. Civ. Eng. 15 (4), 329-337. doi:10.1061/(asce)08873801(2001)15:4(329)

Khosakitchalert, C., Yabuki, N., and Fukuda, T. (2019). Improving the Accuracy of BIM-Based Quantity Takeoff for Compound Elements. Automation in Construction 106, 102891. doi:10.1016/j.autcon.2019.102891

Lange, S., and Schilling, D. (2015). "Reasons for an Optimized Construction Logistics," in Proc. 23rd Ann. Conf. of the IGLC, July 29-31 (Perth: Australia), 733-742.

Le, P. L. (2020). "Optimization of Integrated Construction Supply Chain and BIMBased Logistics Planning,”. Doctoral dissertation (Montreal, Canada: École de technologie supérieure).

Lehtovaara, J., Heinonen, A., Lavikka, R., Ronkainen, M., Kujansuu, P., Ruohomäki, A., et al. (2020). "Takt Maturity Model: From Individual 
Successes towards Systemic Change in Finland," in IGLC. doi:10.24928/2020/ 0017

Leväniemi, M. (2018). Effects of Kitting on Labour Productivity in a Building Renovation Project. Espoo: Aalto University.

Lieb, R. C., Miller, R. A., and Millen, R. A. (1988). JIT and Corporate Transportation Requirements. Transportation J. 1988, 5-10.

Limère, V., Landeghem, H. V., Goetschalckx, M., Aghezzaf, E.-H., and McGinnis, L. F. (2012). Optimising Part Feeding in the Automotive Assembly Industry: Deciding between Kitting and Line Stocking. Int. J. Prod. Res. 50 (15), 4046-4060. doi:10.1080/00207543.2011.588625

Lindén, S., and Josephson, P. E. (2013). In-housing or Out-Sourcing On-Site Materials Handling in Housing? J. Eng. Des. Technol.

Lönngren, H. M., Rosenkranz, C., and Kolbe, H. (2010). Aggregated Construction Supply Chains: success Factors in Implementation of Strategic Partnerships. Supp Chain Mnagmnt 15 (5), 404-411. doi:10.1108/13598541011068297

Maier, A. M., Moultrie, J., and Clarkson, P. J. (2012). Assessing Organizational Capabilities: Reviewing and Guiding the Development of Maturity Grids. IEEE Trans. Eng. Manage. 59, 138-159. doi:10.1109/tem.2010.2077289

Marasco, A. (2008). Third-party Logistics: A Literature Review. Int. J. Prod. Econ. 113 (1), 127-147. doi:10.1016/j.jipe.2007.05.017

Marquès, G., Thierry, C., Lamothe, J., and Gourc, D. (2010). A Review of Vendor Managed Inventory (VMI): from Concept to Processes. Prod. Plann. Control. 21 (6), 547-561. doi:10.1080/09537287.2010.488937

Martin, H., Lewis, T. M., and Fifi, J. (2014). Centralized versus Decentralized Construction Project Structure - Easing Communication Difficulties. Int. J. Construction Manage. 14 (3), 156-170. doi:10.1080/ 15623599.2014 .922726

Martínez-Rojas, M., Marín, N., and Miranda, M. A. V. (2016). An Intelligent System for the Acquisition and Management of Information from Bill of Quantities in Building Projects. Expert Syst. Appl. 63, 284-294. doi:10.1016/ j.eswa.2016.07.011

Mather, H. (1992). Design for Logistics (DFL)-The Next challenge for Designers. Prod. Inventory Manage. J. 33 (1), 7.

McCue, C. P., and Pitzer, J. T. (2000). Centralized vs. Decentralized Purchasing: Current Trends in Governmental Procurement Practices. J. Public Budgeting, Account. Financial Manage. 12 (3), 400-420. doi:10.1108/jpbafm-12-03-2000b003

Merriam and Webster dictionary (2020). Definition of Organize, Viewed 20 October 2020. Available at: https://www.merriam-webster.com/dictionary/ organizing.

Mettler, T., and Rohner, P. (2009). "Situational Maturity Models as Instrumental Artifacts for Organizational Design," in Proceedings of the DESRIST’09, 1-9. doi:10.1145/1555619.1555649

Monteiro, A., and Poças Martins, J. (2013). A Survey on Modeling Guidelines for Quantity Takeoff-Oriented BIM-Based Design. Automation in construction 35, 238-253. doi:10.1016/j.autcon.2013.05.005

Mousharbash, N. (2020). BIM-based Development of Bill of Materials with Case Studies. Master's thesis.

Nitithamyong, P., and Skibniewski, M. J. (2004). Web-based Construction Project Management Systems: How to Make Them Successful? Automation in construction 13 (4), 491-506. doi:10.1016/j.autcon.2004.02.003

Oleśków-Szłapka, J., and Stachowiak, A. (2018). "September. The Framework of Logistics 4.0 Maturity Model," in Int. Conf. on Intelligent Systems in Production Engineering and Maintenance, 771-781.

Patton, M. Q. (1990). Qualitative Evaluation and Research Methods. Thousand Oaks, California, USA: Sage Publications.

Peker, I., Baki, B., Tanyas, M., and Murat Ar, I. (2016). Logistics center Site Selection by ANP/BOCR Analysis: A Case Study of Turkey. J. Intell. Fuzzy Syst.30 (4), 2383-2396. doi:10.3233/ifs-152007

Pheng, L. S., and Hui, M. S. (1999). The Application of JIT Philosophy to Construction: a Case Study in Site Layout. Construction Manage. Econ. 17 (5), 657-668. doi:10.1080/014461999371268

Poon, C. S., Yu, A. T. W., and Jaillon, L. (2004). Reducing Building Waste at Construction Sites in Hong Kong. Construction Manage. Econ. 22 (5), 461-470. doi:10.1080/0144619042000202816

Poshdar, M., González, V. A., and Kasiviswanathan, B. (2018). "Buffer Management in Construction-A New Zealand Study," in Proc. 26th Annual
Conference of the IGLC, Chennai, India. Editor V. A. González, 818-828. doi:10.24928/2018/0517

Ratajczak, J., Schimanski, C. P., Marcher, C., Riedl, M., and Matt, D. T. (2017). "September. Mobile Application for Collaborative Scheduling and Monitoring of Construction Works According to Lean Construction Methods," in International Conference on Cooperative Design, Visualization and Engineering (Cham: Springer), 207-214.

Reddy, A. (2015). The Scrumban [r] Evolution: Getting the Most Out of Agile, Scrum, and Lean Kanban. Boston, Massachusetts, USA: Addison-Wesley Professional.

Riihimäki, M., and Palolahti, T. (2011). Espoo: Rakennusteollisuus RT ry, VTT, Mittaviiva Oy.Rakennustyömaan Toimitusten Ohjaus

Said, H., and El-Rayes, K. (2014). Automated Multi-Objective Construction Logistics Optimization System. Automation in Construction 43, 110-122. doi:10.1016/j.autcon.2014.03.017

Schumacher, A., Erol, S., and Sihn, W. (2016). A Maturity Model for Assessing Industry 4.0 Readiness and Maturity of Manufacturing Enterprises. Proced. CIRP 52, 161-166. doi:10.1016/j.procir.2016.07.040

Segerstedt, A. (2017). Cover-Time Planning/Takt Planning: A Technique for Materials Requirement and Production Planning. Int. J. Prod. Econ. 194, 25-31. doi:10.1016/j.ijpe.2017.04.006

Seow, C., Hillary, R., Robinson, H. S., Anumba, C. J., Carrillo, P. M., and AlGhassani, A. M. (2006). STEPS: a Knowledge Management Maturity Roadmap for Corporate Sustainability. Business Process Manage. J.

Seppänen, O., Ballard, G., and Pesonen, S. (2010). The Combination of Last Planner System and Location-Based Management System. Lean construction J.

Sjödin, D. R., Parida, V., Leksell, M., and Petrovic, A. (2018). Smart Factory Implementation and Process Innovation. Research-Technology Manage. 61 (5), 22-31. doi:10.1080/08956308.2018.1471277

Skjelbred, S., Fossheim, M. E., and Drevland, F. (2015). "Comparing Different Approaches to Site Organization and Logistics: Multiple Case Studies," in 23rd Annual Conference of the International Group for Lean Construction (Perth: Australia), 13-22.

Slack, N., Chambers, S., and Johnston, R. (2010). Operations Management. London, USA: Pearson education.

Song, H., Hsu, V. N., and Cheung, R. K. (2008). Distribution Coordination between Suppliers and Customers with a Consolidation center. Operations Res. 56 (5), 1264-1277. doi:10.1287/opre. 1070.0488

Song, J., Haas, C. T., and Caldas, C. H. (2006). Tracking the Location of Materials on Construction Job Sites. J. Constr. Eng. Manage. 132 (9), 911-918. doi:10.1061/(asce)0733-9364(2006)132:9(911)

Song, M. H., and Fischer, M. (2020). Daily plan-Do-check-act (Pdca) Cycles with Level of Development (Lod) 400 Objects for Foremen. Adv. Eng. Inform. 44, 101091. doi:10.1016/j.aei.2020.101091

Sullivan, G., Barthorpe, S., and Robbins, S. (2011). Managing Construction Logistics. Hoboken, NJ, USA: John Wiley \& Sons.

Sundquist, V., Gadde, L.-E., and Hulthén, K. (2018). Reorganizing Construction Logistics for Improved Performance. Construction Manage. Econ. 36 (1), 49-65. doi:10.1080/01446193.2017.1356931

Suutarla, V. (2016). Using Information Technology in Construction On-Site Logistics Management. Espoo: Aalto University.

Tanskanen, K., Holmström, J., Elfving, J., and Talvitie, U. (2009). Vendormanaged-inventory (VMI) in Construction. Int. J. productivity Perform. Manag. 58 (1), 29-40.

Tanskanen, K., Holmström, J., and Öhman, M. (2015). Generative Mechanisms of the Adoption of Logistics Innovation: the Case of On-Site Shops in Construction Supply Chains. J. Bus Logist 36 (2), 139-159. doi:10.1111/ jbl.12089

Tat, R., Taleizadeh, A. A., and Esmaeili, M. (2015). Developing Economic Order Quantity Model for Non-instantaneous Deteriorating Items in VendorManaged Inventory (VMI) System. Int. J. Syst. Sci. 46 (7), 1257-1268. doi:10.1080/00207721.2013.815827

Tellis, W. (1997). Application of a Case Study Methodology. Qual. Rep. 3 (3), 1-19. doi:10.46743/2160-3715/1997.2015

Tetik, M., Peltokorpi, A., Holmström, J., and Seppänen, O. (2018). "Impacts of an Assembly Kit Logistic Solution in Renovation Projects: a Multiple Case Study with Camera-Based Measurement," in 25th Annual EurOMA Conference. 
Tetik, M., Peltokorpi, A., Seppänen, O., and Holmström, J. (2019). Direct Digital Construction: Technology-Based Operations Management Practice for Continuous Improvement of Construction Industry Performance. Automation in construction 107, 102910. doi:10.1016/j.autcon.2019.102910

Tetik, M., Peltokorpi, A., Seppänen, O., Leväniemi, M., and Holmström, J. (2020). Kitting Logistics Solution for Improving On-Site Work Performance in Construction Projects. J. Construction Eng. Manage. 147 (1), 05020020.

Tetik, M., Peltokorpi, A., Seppänen, O., Viitanen, A., and Lehtovaara, J. (2019). "Combining Takt Production with Industrialized Logistics in Construction," in IGLC, Ireland, Dublin. doi:10.24928/2019/0156

Thomas, H. R., Sanvido, V. E., and Sanders, S. R. (1989). Impact of Material Management on Productivity-A Case Study. J. Construction Eng. Manage. 115 (3), 370-384. doi:10.1061/(asce)0733-9364(1989)115:3(370)

Thunberg, M., and Persson, F. (2014). Using the Scor Model's Performance Measurements to Improve Construction Logistics. Prod. Plann. Control. 25 (13-14), 1065-1078. doi:10.1080/09537287.2013.808836

Tian, Y., Ellinger, A. E., and Chen, H. (2010). Third-party Logistics Provider Customer Orientation and Customer Firm Logistics Improvement in China. Int. Jnl Phys. Dist Log Manage. 40 (5), 356-376. doi:10.1108/ 09600031011052822

Tommelein, I., and Li, A. (1999). "Just-in-time concrete Delivery: Mapping Alternatives for Vertical Supply Chain integration.”. Proc. IGLC 7, 97.

Vaidyanathan, K., and Howell, G. (2007). "Construction Supply Chain Maturity Model-Conceptual Framework," in Proceedings IGLC, Vol. 15, 170-180.

Vatne, M. E., and Drevland, F. (2016). Practical Benefits of Using Takt Time Planning: A Case Study. IGLC 173, 173-182.

Vigtil, A. (2007). Information Exchange in Vendor Managed Inventory. Int. J. Phys. Distribution Logistics Manage. 37 (2), 131-147. doi:10.1108/ 09600030710734848

Vrijhoef, R., and Koskela, L. (2000). The Four Roles of Supply Chain Management in Construction. Eur. J. Purchasing Supply Manage. 6 (3-4), 169-178. doi:10.1016/s0969-7012(00)00013-7

Waller, M., Johnson, M. E., and Davis, T. (1999). Vendor-managed Inventory in the Retail Supply Chain. J. business logistics 20, 183-204.

Wambeke, B. W., Hsiang, S. M., and Liu, M. (2011). Causes of Variation in Construction Project Task Starting Times and Duration. J. Constr. Eng. Manage. 137(9), 663-677. doi:10.1061/(asce)co.1943-7862.0000342

Wegelius-Lehtonen, T., and Pahkala, S. (1998). Developing Material Delivery Processes in Cooperation: an Application Example of the Construction Industry. Int. J. Prod. Econ. 56-57, 689-698. doi:10.1016/s0925-5273(98) 00077-2

Werner-Lewandowska, K., and Kosacka-Olejnik, M. (2018). Logistics Maturity Model for Service Company - Theoretical Background. Proced. Manufacturing 17, 791-802. doi:10.1016/j.promfg.2018.10.130
Woo, S., Jeong, S., Mok, E., Xia, L., Choi, C., Pyeon, M., et al. (2011). Application of WiFi-Based Indoor Positioning System for Labor Tracking at Construction Sites: A Case Study in Guangzhou MTR. Automation in Construction 20 (1), 3-13. doi:10.1016/j.autcon.2010.07.009

Yao, Y., and Dresner, M. (2008). The Inventory Value of Information Sharing, Continuous Replenishment, and Vendor-Managed Inventory. Transportation Res. E: Logistics Transportation Rev. 44 (3), 361-378. doi:10.1016/ j.tre.2006.12.001

Yin, R. K. (2013). Case Study Research: Design and Methods. Thousand Oaks, California, USA: Sage publications.

Ying, F., Tookey, J., and Roberti, J. (2014). Addressing Effective Construction Logistics through the Lens of Vehicle Movements. Eng. construction architectural Manag. 21, 261. doi:10.1108/ecam-06-2013-0058

Zhao, J., Olivieri, H., Seppänen, O., Peltokorpi, A., Badihi, B., and Lundström, P. (2017). "Data Analysis on Applying Real Time Tracking in Production Control of Construction," in 2017 IEEE Int. Conf. on Industrial Engineering and Engineering Management (IEEM), 573-577. doi:10.1109/ieem.2017.8289956

Zhao, J., Seppänen, O., Peltokorpi, A., Badihi, B., and Olivieri, H. (2019). Real-time Resource Tracking for Analyzing Value-Adding Time in Construction. Automation in Construction 104, 52-65. doi:10.1016/j.autcon.2019.04.003

Zhao, J., Zhang, J., and Seppänen, O. (2019). "Real-time Tracking for Intelligent Construction Site Platform in Finland and China: Implementation Data Analysis and Use Cases," in ISARC Procs, 62-68. doi:10.22260/isarc2019/0009

Zheng, Y., Tetik, M., Törmä, S., Peltokorpi, A., and Seppänen, O. (2020). "A Shared Ontology for Logistics Information Management in the Construction Industry," in 37th ISARC 2020. doi:10.22260/isarc2020/0175

Conflict of Interest: The authors declare that the research was conducted in the absence of any commercial or financial relationships that could be construed as a potential conflict of interest.

Publisher's Note: All claims expressed in this article are solely those of the authors and do not necessarily represent those of their affiliated organizations, or those of the publisher, the editors, and the reviewers. Any product that may be evaluated in this article, or claim that may be made by its manufacturer, is not guaranteed or endorsed by the publisher.

Copyright (๑ 2022 Tetik, Peltokorpi, Seppänen and Holmström. This is an openaccess article distributed under the terms of the Creative Commons Attribution License (CC BY). The use, distribution or reproduction in other forums is permitted, provided the original author(s) and the copyright owner(s) are credited and that the original publication in this journal is cited, in accordance with accepted academic practice. No use, distribution or reproduction is permitted which does not comply with these terms. 